\title{
Chemical, mineralogical and morphological changes in weathered coal fly ash: A case study of a brine impacted wet ash dump
}

Chuks P. Eze, Sammy M. Nyale, Richard O. Akinyeye, Wilson M. Gitari, Segun A. Akinyemi, Olanrewaju O. Fatoba and Leslie F. Petrik

\section{Abstract}

The mobility of species in coal fly ash (FA), co-disposed with brine using a wet ash handling system, from a coal fired power generating utility has been investigated. The study was conducted in order to establish if the wet ash dump could act as a salt sink. The ash was dumped as a slurry with 5:1 brine/ash ratio and the dam was in operation for 20 years. Weathered FA samples were collected along three cores at a South African power station's wet ash dump by drilling and sampling the ash at $1.5 \mathrm{~m}$ depth intervals. A fresh FA sample was collected from the hoppers in the ash collection system at the power station. Characterization of both fresh FA and weathered FA obtained from the drilled cores $\mathrm{S}_{1}, \mathrm{~S} 2$ and $\mathrm{S}_{3}$ was done using X-ray diffraction (XRD) for mineralogy, X-ray fluorescence (XRF) for chemical composition and scanning electron microscopy (SEM) for morphology. Analysis of extracted pore water and moisture content determination of the fresh FA and the weathered FA obtained from the drilled cores $\mathrm{S}_{1}, \mathrm{~S}_{2}$ and $\mathrm{S}_{3}$ was done in order to evaluate the physico-chemical properties of the FA. The XRD analysis revealed changes in mineralogy along cores $\mathrm{S} 1, \mathrm{~S} 2$ and $\mathrm{S} 3$ in comparison with the fresh FA. The SEM analysis revealed spherical particles with smooth outer surfaces for the fresh FA while the weathered ash samples obtained from cores $\mathrm{S} 1, \mathrm{~S} 2$ and $\mathrm{S}_{3}$ consisted of agglomerated, irregular particles appearing to be encrusted, etched and corroded showing that weathering and leaching had occurred in the ash dump. The moisture content (MC) analysis carried out on the fresh FA (1.8\%) and the weathered FA obtained from the drilled cores $\mathrm{S}_{1}$ (41.4-73.2\%), S2 (30.3-94\%) and $\mathrm{S}_{3}$ (21.7-76.2\%)indicated that the ash dump was water logged hence creating favourable conditions for leaching of species. The fresh fly ash $(n=3)$ had a $\mathrm{pH}$ of $12.38 \pm 0.15$, EC value of $4.98 \pm 0.03 \mathrm{mS} / \mathrm{cm}$ and TDS value of $2.68 \pm$ $0.03 \mathrm{~g} / \mathrm{L}$, the $\mathrm{pH}$ of the drilled core $\mathrm{S} 1(\mathrm{n}=45)$ was $10.04 \pm 0.50$, the EC value was $1.08 \pm 0.14 \mathrm{mS} / \mathrm{cm}$ and the TDS value was $0.64 \pm 0.08 \mathrm{~g} / \mathrm{L}$. Core $\mathrm{S} 2(\mathrm{n}=105) \mathrm{had} \mathrm{pH}$ of $10.04 \pm 0.23$; EC was $1.08 \pm 0.06 \mathrm{mS} / \mathrm{cm}$ and TDS was $0.64 \pm 0.04 \mathrm{~g} / \mathrm{L}$, while core $\mathrm{S}_{3}(\mathrm{n}=66) \mathrm{had} \mathrm{pH}$ of $11.04 \pm 0.09$; EC was $0.99 \pm 0.03 \mathrm{mS} / \mathrm{cm}$ and TDS was $0.57 \pm 0.01 \mathrm{~g} / \mathrm{L}$. The changes in $\mathrm{pH}$ values 
can be attributed to the dissolution and flushing out of alkaline oxides like $\mathrm{CaO}$ and $\mathrm{MgO}$ from the dumped ash. The variations in $\mathrm{pH}$ values shows that the fly ash is acidifying over time and metal mobility can be expected under these conditions. The large decrease of EC in the drilled ash cores S1, S2 and S3 compared to the fresh ash indicated a major loss of ionic species over time in the ash dump. The XRF analysis showed the progressive dissolution of the major alumi-nosilicate ash matrix which influenced the release of minor and trace elements into the pore water enhancing their mobility as the ash dam acidified over time. Brine co-disposal on the ash may have been responsible for the slight enrichment of some species such as $\mathrm{Na}$ (0.27$0.56 \%), \mathrm{SO}_{4}$ (0.06-0.08\%), $\mathrm{Mg}(0.57-0.96 \%)$ and $\mathrm{K}(0.02-0.34 \%)$ in the disposed weathered FA. However, there was no significant accumulation of these species in the disposed FA despite continuous addition of large volumes of highly saline brine over the 20 year period that the dump existed, indicating that the ash dam was incapable of holding salts and continually released elements to the environment over the lifetime of the dam.

\section{Introduction}

South Africa (SA) has abundant coal reserves which are utilized to generate electricity and petrochemical related products. Sasol, which is one of Africa's major producers of chemicals and liquid fuels, and Eskom, the major power utility company in SA are the biggest consumers of coal in the country. The Sasol complex located at Secunda in SA operated by Sasol Synfuels (Pty) Ltd is the world's largest commercial coal-to-liquids (CTL) facility (Mangena, 2009). Sasol Secunda utilizes low rank bituminous coal in its gasification and combustion processes to produce synthesis gas and steam respectively. Sasol Secunda utilizes approximately 28 million tons of coal annually, out of which $70 \%$ (coarse coal) is used as feedstock for its gasification process while the remaining $30 \%$ (finer coal fraction) is used in steam and electric power production. A mixture of coarse and fine ash particles is produced as a byproduct of the gasification process and FA as the by-product of the combustion process (Matjie et al., 2005; Hlatshwayo et al., 2009).

FA is the fine particulate waste product that results during the combustion of pulverised coal to generate electricity. FA travels with the flue gases and is removed from the flue gas stream using either electrostatic precipitators or bag filters to avoid release into the atmosphere. FA consists of inorganic and organic components (Liu et al., 2005; Vassilev and Vassileva, 2005). The mineral components in FA have natural and anthropogenic origins and can be classified as primary, secondary and tertiary. The primary mineral phases originate from the parent coal and do not undergo phase transformation during coal combustion; the secondary mineral phases are formed during coal combustion while the tertiary mineral phases are formed during the handling and storage of the FA (Vassilev and Vassileva, 2005).

\section{http://repository.uwc.ac.za}


SA generated about 30 million tons of FA in 2003 of which only about 1.2 million tons was beneficiated (Potgieter, 2003). However, in 2009, Eskom alone generated nearly 36.7 million tons of FA from coal combustion, of which only $5.7 \%$ was beneficiated (www. eskom.co.za). Thus the bulk of the FA generated is disposed in ponds or dry surfaces. FA is mainly disposed using either the dry or wet disposal method. In the dry disposal method, the FA is transported by truck, chute or conveyor at the power plant and disposed by constructing a dry embankment; the ash heap is then irrigated with brine for dust suppression. In the wet disposal method, the FA is blended with brine and is then transported as slurry with liquid: solid ratio of 1:5 through pipes and disposed in an impoundment referred to as ash pond or dam (Akinyemi, 2011).

Various environmental risks are associated with FA disposal, these include air pollution, loss of arable land and surface and ground water contamination due to the leaching of toxic and non-degradable metals, and other chemical species from the ash dump (Vadapalli et al., 2010; Potgieter-Vermaak et al., 2005). The management and long term disposal of FA is a major concern and requires the proper understanding of the weathering trends of FA. The huge amount of FA that is disposed cannot be separated from nature's weathering cycle as the FA dumps are exposed to ash disposal water, air and rainfall. The weathering of FA results in changes in the physical, chemical and mineralogical properties such as the formation of secondary mineral phases (Yeheyis et al., 2009), decrease in the $\mathrm{pH}$ and $\mathrm{EC}$ of the pore water in the FA (Ward et al., 2009; Baba et al., 2008; Gitari et al., 2009; Ugurlu, 2004) and reduction of soluble salt content (Brower, 1985) which may have a significant effect on the leaching and mobilization of the FA species (Zevenbergen et al., 1999; Yeheyis et al., 2009). Understanding the changes in the chemical, physical, morphological properties and phase transformation of FA is vital in predicting the environmental impact associated with FA disposal.

This study focuses on the changes in the chemical, physical, morphological properties and mineral phase transformation that occurred during the disposal or storage of the brine impacted coal FA. The design and operation of the ash dump is based on the assumption that presupposed that the dumped FA may act as a sink for the salts which mainly originated from the brines generated during desalination procedures used at the power station. This study aims at understanding the weathering patterns of the disposed FA in the wet ash handling system over time and understanding the environmental impact associated with the FA disposal technique in order to ascertain whether the ash dump could act as a sustainable salt sink.

\section{http://repository.uwc.ac.za}




\section{Materials and methods \\ 2.1. Sampling}

The FA samples used in this study were collected from an ash dump at a petrochemical utility station in the Mpumalanga province in SA. The ash dump consisted of $87 \%$ FA from the combustion of pulverised coal to produce steam and electric power and $13 \%$ fine ash from coal gasification processes. The particle size of the fine ash ranged between $20 \leq 50 \mu \mathrm{m}$ as given by the scientific officer at the petrochemical utility plant. The samples obtained from the ash dump were wet and required drying and milling hence it was not possible to determine the original particle size due to the disposal method used in the dump. The ash disposed at the dump was pumped as a slurry of 5:1 water/ash ratio using the high saline stream (brine) that was generated from the water treatment processes in the power station. The dump site was created in 1989 and dumping stopped in 2009. The oldest layer at the bottom of the ash dump was 20 years old while the youngest layer at the top of the ash dump was 1 year old. The geophysics electrical resistivity survey profile (Fig. 1) shows the position of the three cores drilled at the FA dump. Core S1 was drilled at $960 \mathrm{~m}$ (Lat 26.560411, long 29.119348) while core S2 was drilled at $800 \mathrm{~m}$ (Lat 26.559099, long 29.119039). Core $\mathrm{S}_{3}$ was drilled at $600 \mathrm{~m}$ (Lat 26.557826, long 29.118943). The positions of cores S1 and S2 were selected based on the moisture content levels, with the latter core showing slightly lower moisture content compared to core S1. The position of core $\mathrm{S}_{3}$ was selected because of the geological fault line visible in the geophysics profile (Fig. 1). A combination of air flush coring and standard percussion drilling was used to drill the cores from the ash dump. During the coring process of core S1, the drilling stopped at $22.5 \mathrm{~m}$ due to an unknown obstruction in the dump that prevented the auger from proceeding further. The drilling of cores S2 and S3 stopped at $51 \mathrm{~m}$ and $31.5 \mathrm{~m}$ respectively. The fresh FA samples used for comparative analysis in this study were collected from the hoppers inside the ash collection system at the coal burning power station of the petrochemical facility.

\subsection{Experimental procedures 2.2.1. X-ray fluorescence (XRF)}

The bulk chemical composition of the fresh FA sample and the drilled cores S1, S2 and S3 were determined using XRF spectrometry. The samples for XRF analysis were taken at $1.5 \mathrm{~m}$ depth intervals along the drilled cores. The core ash samples were oven-dried at $100{ }^{\circ} \mathrm{C}$ for $12 \mathrm{~h}$ to remove adsorbed water prior to analysis, and milled to a uniform size grained powder. The powder samples were then mixed with a binder (ratio of 1:9). The powder mixture was then pelletized at a pressure of 15 Kbars. Loss on ignition (LOI) experiment was performed prior to major element analysis and for accuracy of the analytical results. A Phillips PAN-alytical pw1480 X-ray fluorescence spectrometer using a rhodium tube as the X-ray source was used. The

\section{http://repository.uwc.ac.za}


technique reports concentration as \% oxides for major elements and ppm for trace elements. Elements reported as \% oxides were converted to \% elements using element conversion software downloaded from http:// www.marscigrp.org/oxtoel.html. All the samples were analysed in triplicates.

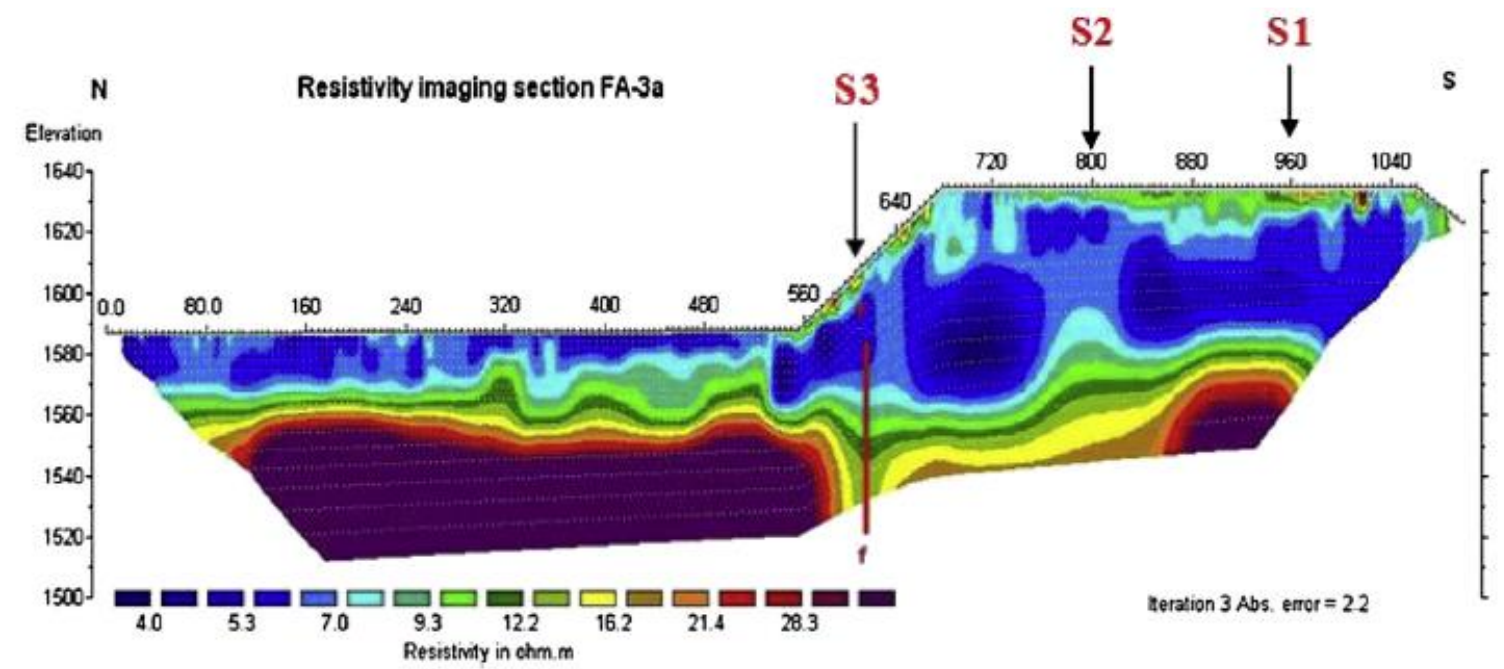

Fig 1. Resistivity mapping of the wet disposed ash dump showing positions for cores $\mathrm{S} 1, \mathrm{~S} 2$ and $\mathrm{S} 3$. 

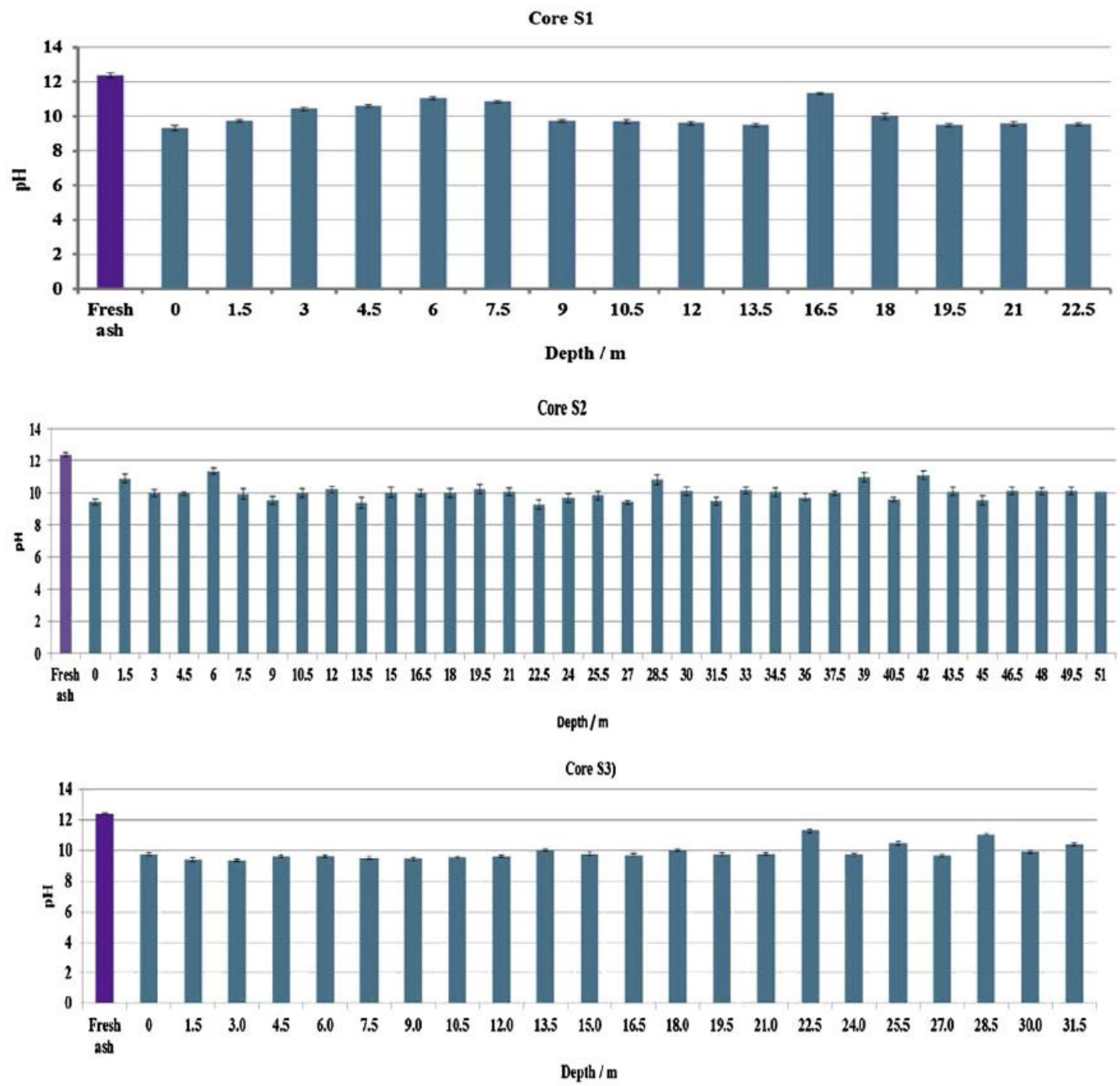

Fig. 2. $\mathrm{pH}$ of the fresh FA sample and the samples from weathered drilled cores S1, S2 and S3[number of determinations for fresh ash, S1, S2 and S3 are 3, 45,105 and 44 respectively]. 


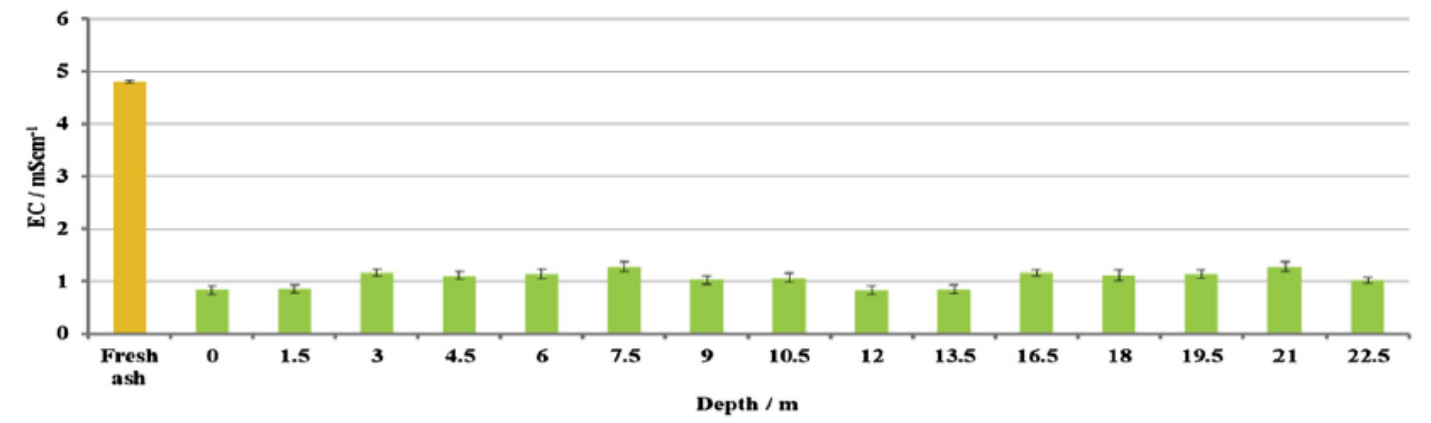

Core $\mathbf{2}$
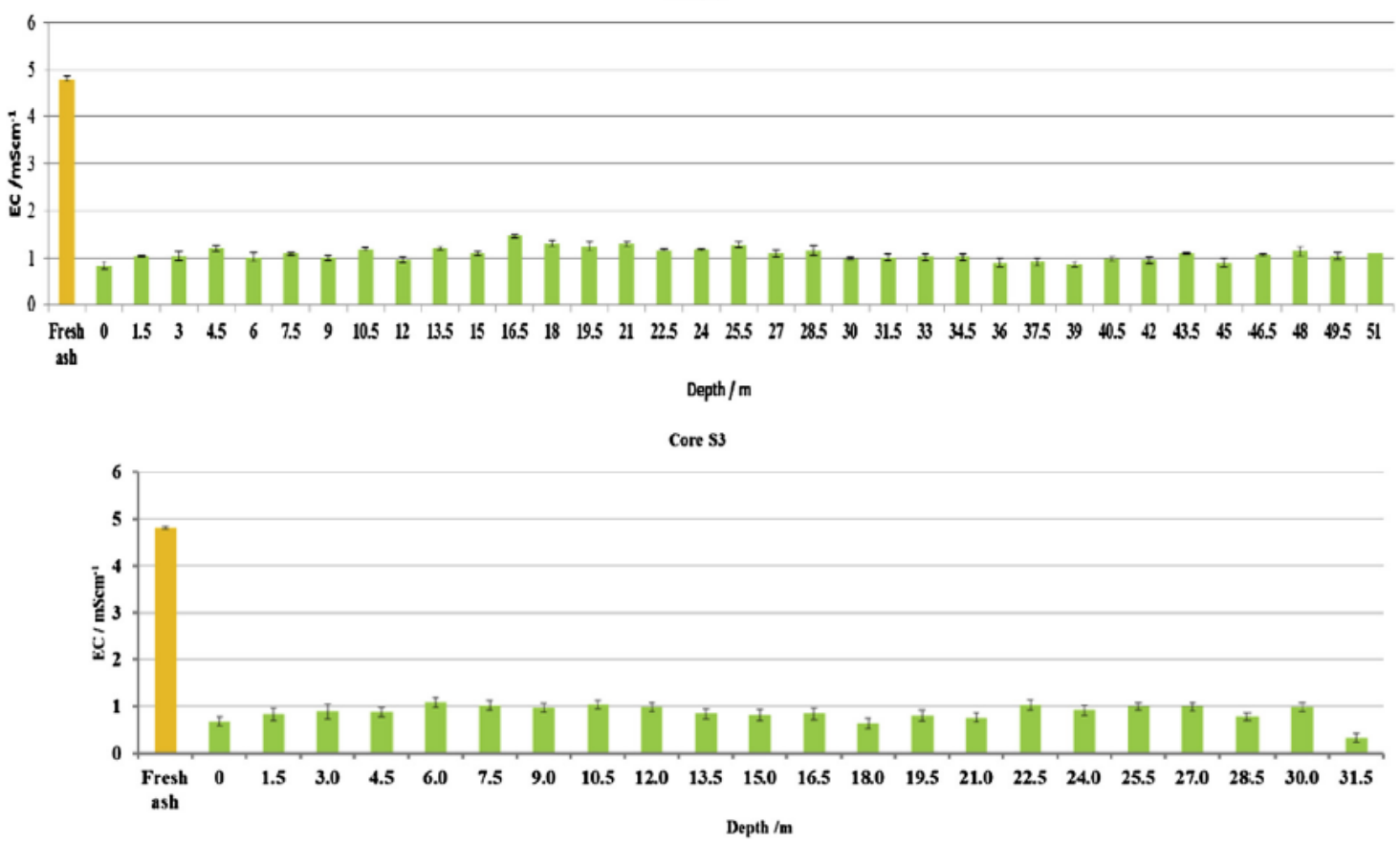

Fig. 3. EC of the fresh FA sample and the samples from weathered drilled cores S1, S2 and S3 [number of determinations for fresh ash, S1, S2 and S3 are 3, 45, 105 and 44 respectively].

\subsubsection{Pore water analysis}

The $\mathrm{pH}$, electrical conductivity (EC) and total dissolved solids (TDS) of the interstitial/pore water was determined using a solid: water ratio of 1:10. $10 \mathrm{~g}$ of the fresh FA sample and each of the FA samples extracted from cores $\mathrm{S} 1, \mathrm{~S} 2$ and $\mathrm{S} 3$ at $1.5 \mathrm{~m}$ intervals down the profile of the ash dump were weighed and put in beakers and each suspended in $100 \mathrm{ml}$ of ultra-pure water. The samples were then agitated thoroughly for $30 \mathrm{~min}$ and allowed to settle for $15 \mathrm{~min}$. The $\mathrm{pH}$, EC and TDS of the supernatants were recorded at room temperature. A portable, waterproof Hanna $\mathrm{pH}$ meter series $\mathrm{HI}$ 991301N was used. The meter reports $\mathrm{EC}$ in $\mathrm{mS} / \mathrm{cm}$ and TDS in ppt (g/L) (www.hannaist.com).

\subsubsection{Moisture content determination}

The moisture content of the fresh FA sample and the drilled cores $\mathrm{S} 1, \mathrm{~S} 2$ and S3 was carried out by drying $5 \mathrm{~g}$ of each FA sample in an oven at $105^{\circ} \mathrm{C}$ for $24 \mathrm{~h}$. 
The samples were then allowed to cool down and weighed again. The percentage moisture content was then calculated from the difference in weight of each sample (Standards Association of Australia, 1977) as shown below:

$$
\% \text { Moisture }=\frac{\text { Change in weight of sample after drying }}{\text { Weight of sample after drying }} \times 100
$$

\subsubsection{Scanning electron microscopy (SEM)}

The scanning electron microscopy analysis was carried out on the fresh FA sample and the samples from the drilled cores S1, S2 and S3 using a Nova Nano SEM 230 equipped with an Oxford X-max detector. The FA samples were ovendried at $105{ }^{\circ} \mathrm{C}$ for $12 \mathrm{~h}$ in preparation for the analysis. The dried samples were speckled on special glue mixed with carbon graphite. Each sample was then mounted into specimen holders and the morphology and texture determined.

\subsubsection{X-ray diffraction (XRD)}

The fresh FA sample and the samples taken from the drilled cores S1, S2 and S3 were analysed for consistent mineral phases using XRD. A Philips PANalytical instrument with a pw3830 X-ray generator operated at $40 \mathrm{kV}$ and 25 $\mathrm{mA}$ was used. The samples were step-scanned from 5 to $85^{\mathrm{O}} 2$ theta scale at intervals of $0.02^{\mathrm{O}}$ and counted for $0.5 \mathrm{~s}$ per step. 
Core S1
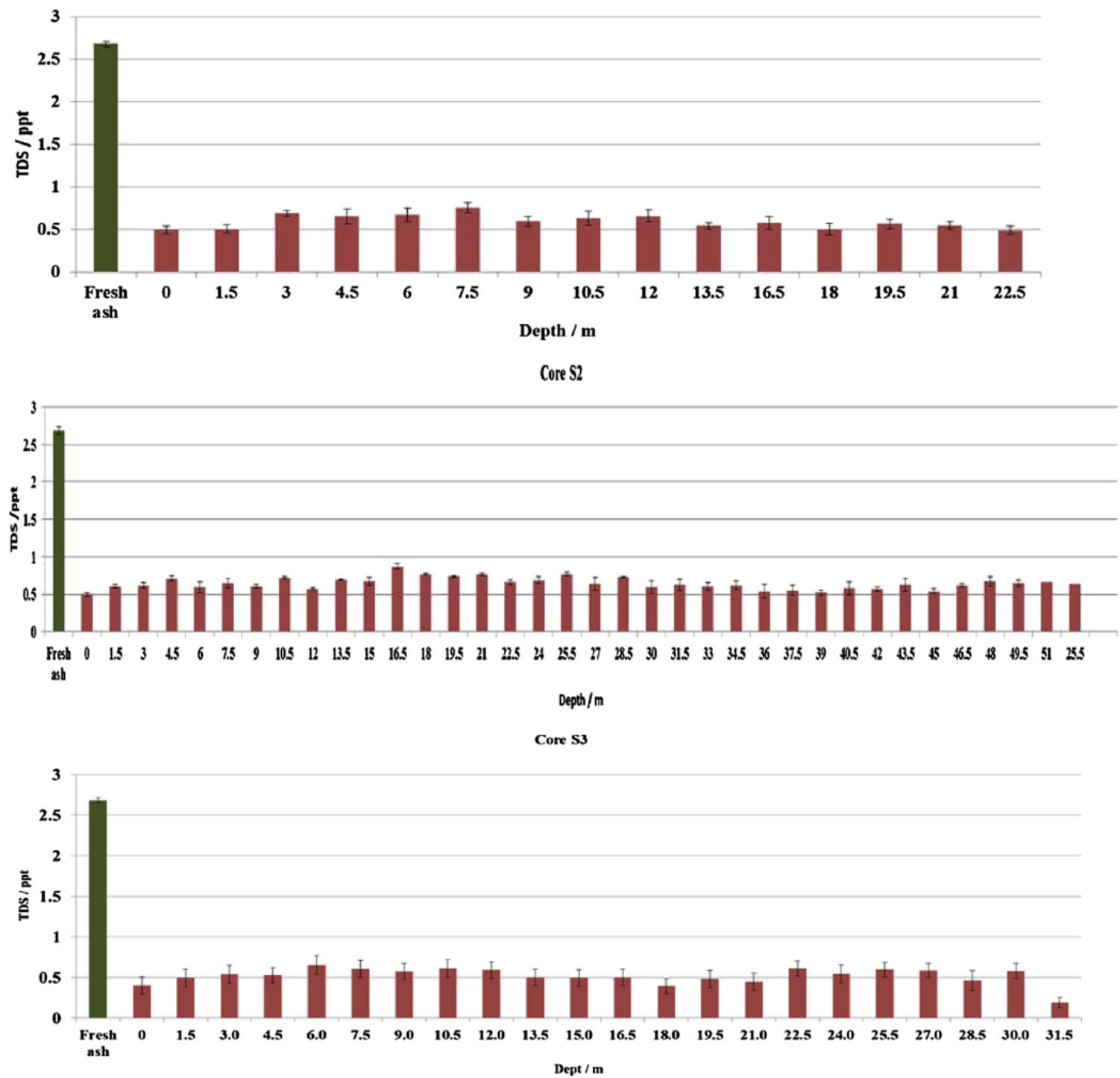

Fig. 4. TDS of the fresh FA sample and the weathered drilled cores S1, S2 and S3 [number of determinations for fresh ash, S1, S2 and S3 are 3, 45,105 and 44 respectively].

\section{Results and discussion \\ 3.1. $\mathbf{p H}$}

Fig. 2 shows the $\mathrm{pH}$ profile of the fresh FA sample and the samples taken from the weathered drilled cores $\mathrm{S}_{1}, \mathrm{~S}_{2}$ and $\mathrm{S}_{3}$ as a function of depth. The $\mathrm{pH}$ analysis (Fig. 2) shows that the fresh FA sample had a $\mathrm{pH}$ of 12.38. For the samples taken from drilled core $\mathrm{S} 1$, the $\mathrm{pH}$ was between 9.33 at the surface and 11.32 at $16.5 \mathrm{~m}$ (Fig. 2). The $\mathrm{pH}$ for core $\mathrm{S} 2$ was between 9.29 at $22.5 \mathrm{~m}$ and 11.36 at $6 \mathrm{~m}$ while the $\mathrm{pH}$ for core $\mathrm{S} 3$ was between 9.32 at $3 \mathrm{~m}$ and 11.27 at 22.5 $\mathrm{m}$ (Fig. 2). The $\mathrm{pH}$ values show that the FA samples are alkaline. There is a significant decrease in $\mathrm{pH}$ in the drilled cores $\mathrm{S} 1, \mathrm{~S} 2$ and $\mathrm{S} 3$ compared to the fresh FA. These variations in $\mathrm{pH}$ show that the dumped FA is acidifying over time, therefore metal mobility in the ash dump can be expected under these conditions. The acidification of the dumped weathered ash could be attributed 
to the chemical interactions of the ash with the co-disposed brine as well as with the atmospheric $\mathrm{CO}_{2}$ and percolating rain water, leading to the dissolution and consequent reduction of the alkaline materials such as $\mathrm{CaO}$ present in the FA (Saikia et al., 2006). Eqs. (1)e(3) illustrate how CaO is lost from the dumped FA through conversion into soluble calcium bicarbonate.

$$
\mathrm{CaO}+\mathrm{H}_{2} \mathrm{O} \rightarrow \mathrm{Ca}(\mathrm{OH})_{2}
$$

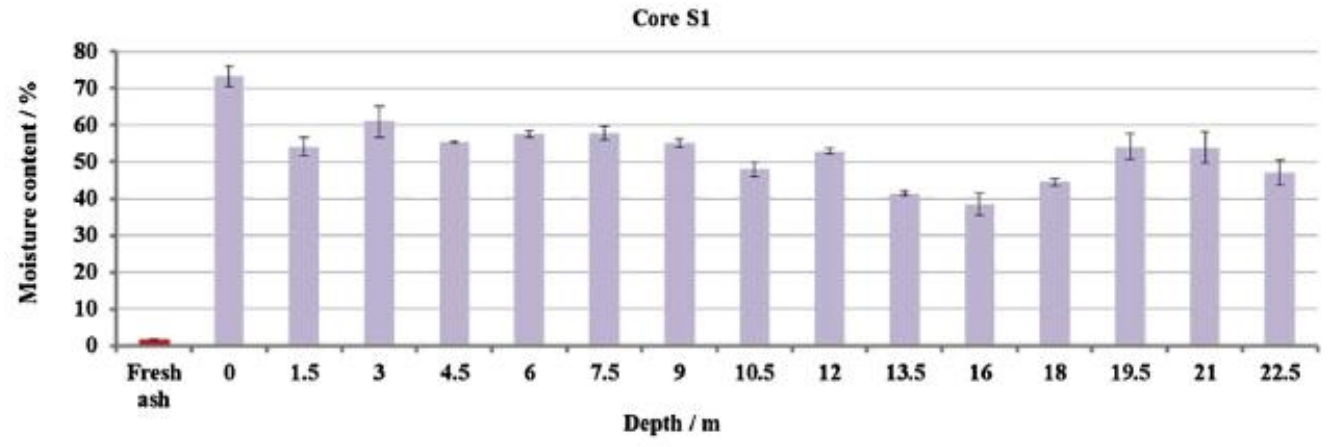

S2

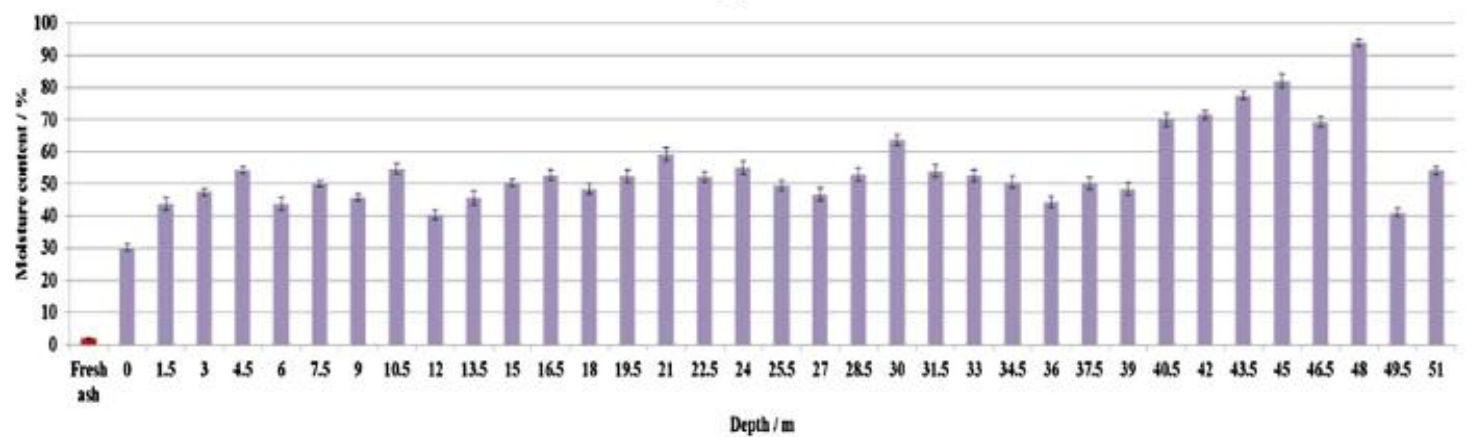

Core $\mathbf{5 3}$

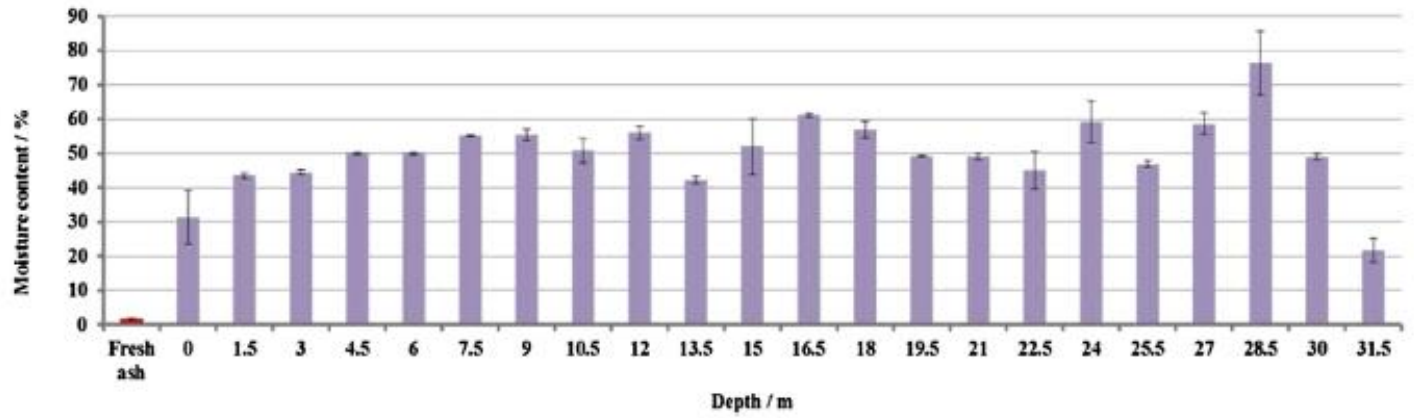

Fig. 5. Moisture content profile of the fresh FA sample and the samples from the weathered drilled cores $\$ 1, \$ 2$ and $\$ 3$ [number of determinations for fresh ash, $\mathrm{S1}, \mathrm{S} 2$ and $\mathrm{S} 3$ are 3 , 45,105 and 44 respectively].

hydration of lime in the FA into calcium hydroxide suspension as a result of brine and infiltrating rain water in the ash dam

$$
\mathrm{Ca}(\mathrm{OH})_{2}+\mathrm{CO}_{2} \rightarrow \mathrm{CaCO}_{3}+\mathrm{H}_{2} \mathrm{O}
$$


carbonation of calcium hydroxide, by ingressed carbon dioxide in the ash dam, into calcium carbonate

$$
\mathrm{CaCO}_{3}+\mathrm{H}_{2} \mathrm{O}+\mathrm{CO}_{2} \rightarrow \mathrm{Ca}\left(\mathrm{HCO}_{3}\right)_{2}
$$

reaction of calcium carbonate with water and carbon dioxide in the ash dam to form soluble calcium bicarbonate.

The $\mathrm{pH}$ variations affect the mobility of the chemical species in the FA effectively dictating the element mobility patterns within the ash dam (Petrik et al., 2010; Ward et al., 2009). According to Dutta et al. (2009), pH is the major factor affecting element mobility and leaching patterns in FA. For most elements there is higher element release (more leaching) at low $\mathrm{pH}$ and vice versa. Other factors that may play a role in element mobility and leaching patterns in FA include ash and water contact time and solideliquid ratio.

\subsection{Electrical conductivity (EC)}

Fig. 3 shows the EC profile of the fresh FA sample and the weathered drilled cores $\mathrm{S}_{1}, \mathrm{~S} 2$ and $\mathrm{S}_{3}$ as a function of depth. The EC of the fresh FA sample was observed to be $4.92 \mathrm{mS} / \mathrm{cm}$ (Fig. 3). For the drilled core S1, the EC was between $0.83 \mathrm{mS} / \mathrm{cm}$ at the surface and $1.28 \mathrm{mS} / \mathrm{cm}$ at $7.5 \mathrm{~m}$ while the EC for core $\mathrm{S} 2$ was between $0.85 \mathrm{mS} / \mathrm{cm}$ at the surface and $1.46 \mathrm{mS} / \mathrm{cm}$ at $16.5 \mathrm{~m}$. The EC for core $\mathrm{S}_{3}$ was between $0.32 \mathrm{mS} / \mathrm{cm}$ at $31.5 \mathrm{~m}$ and $1.08 \mathrm{mS} / \mathrm{cm}$ at $6 \mathrm{~m}$ (Fig. 3). The EC is governed by the amount of ions present in the extracted pore water. Therefore, high EC observed in the fresh FA indicates the release of more ionisable species from the FA into the solution while the lower EC observed in the core samples means lesser amount of ions are present in the aqueous extract. The lower EC observed in the drilled cores S1, S2 and S3 compared to the fresh FA indicates a significant loss of ionic species from the dumped weathered ash. This observation may be as a result of leaching of the ash through infiltrating brine and rainwater, leading to loss of the ionic species from the disposed ash into the ground water (Bhattacharyya et al., 2009; Petrik et al., 2010). 


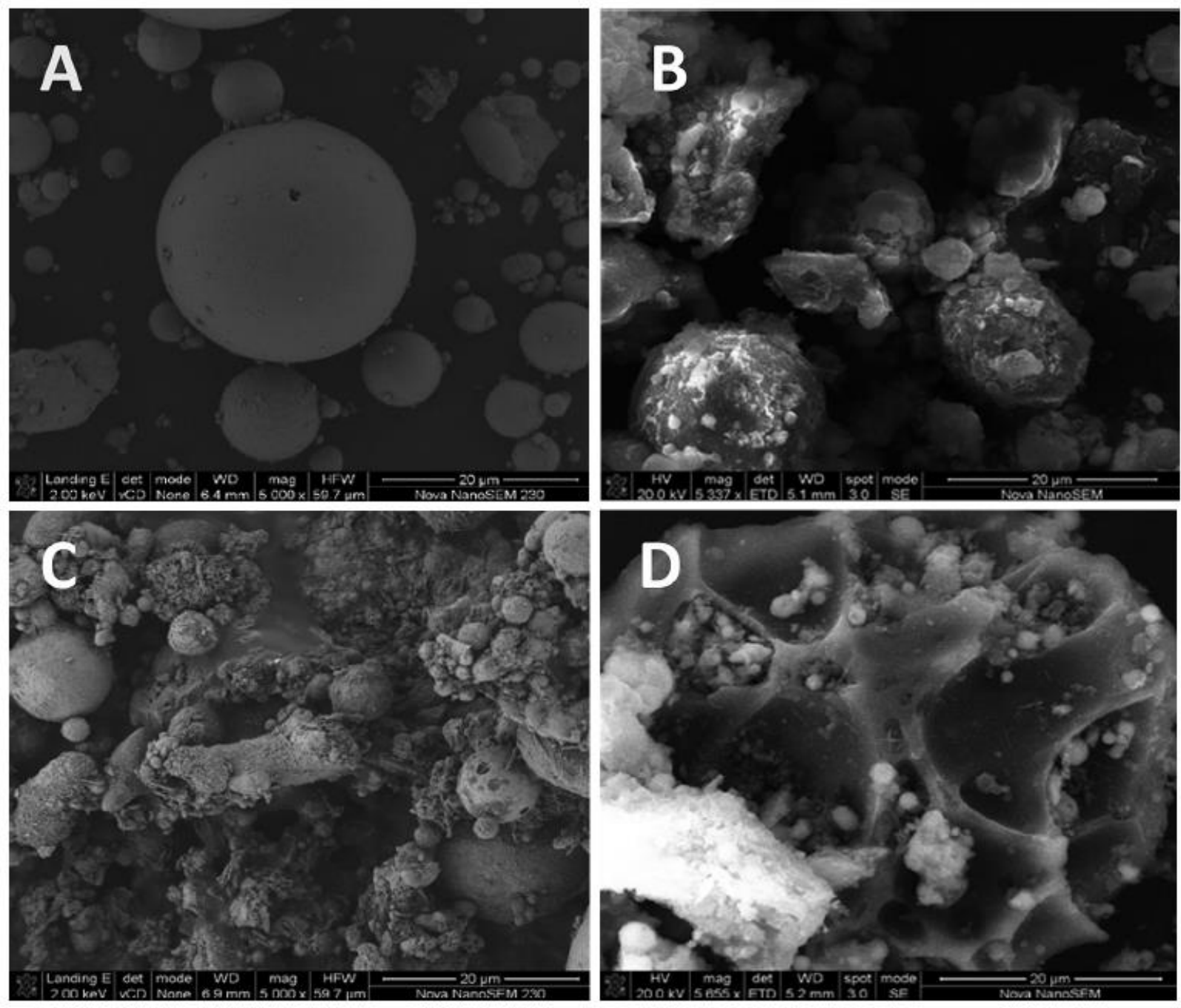

Fig. 6. SEM micrographs of ash samples: A for fresh, B, C, D for cores S1, S2 and S3 respectively.

\subsection{Total dissolved solids (TDS)}

Fig. 4 shows the TDS profile of the fresh FA sample and the weathered drilled cores S1, S2 and S3 as a function of depth. The TDS of the fresh FA sample was $2.68 \mathrm{~g} / \mathrm{L}$ (Fig. 4). For the drilled core S1, the TDS was between $0.49 \mathrm{~g} / \mathrm{L}$ at $22.5 \mathrm{~m}$ and $0.76 \mathrm{~g} / \mathrm{L}$ at $7.5 \mathrm{~m}$ while the TDS for core $\mathrm{S} 2$ was between $0.5 \mathrm{~g} / \mathrm{L}$ at the surface and $0.87 \mathrm{~g} / \mathrm{L}$ at $16.5 \mathrm{~m}$. The TDS for core $\mathrm{S}_{3}$ was between $0.19 \mathrm{~g} / \mathrm{L}$ at $31.5 \mathrm{~m}$ and $0.68 \mathrm{~g} / \mathrm{L}$ at $6 \mathrm{~m}$ (Fig. 4). The TDS data were indicative of the relative release and entrapment of various elements during weathering. The TDS essentially followed the same trend as that observed for the EC. The TDS profiles of the drilled cores $\mathrm{S}_{1}, \mathrm{~S}_{2}$ and $\mathrm{S}_{3}$ show a significant decrease in comparison to the fresh FA (Fig. 4). This decrease indicates the extent of leaching and poor salt sink capacity of the FA dump since the TDS would have been considerably higher in the drilled cores $\mathrm{S} 1, \mathrm{~S} 2$ and $\mathrm{S}_{3}$ if the FA dump was holding salts. 


\subsection{Moisture content (MC)}

Fig. 5 shows the moisture content of the fresh FA sample and the moisture profile of samples from the weathered drilled cores $\mathrm{S}_{1}, \mathrm{~S}_{2}$ and $\mathrm{S}_{3}$ as a function of depth. The MC of the fresh FA sample was 1.8\% (Fig. 5). For the samples taken from the drilled core $\mathrm{S} 1$, the $\mathrm{MC}$ ranged between $41.4 \%$ and $73.2 \%$ while the $\mathrm{MC}$ for core S2 ranged between 30.3\% and 94\% (Fig. 5). The MC for core S3 ranged between $21.7 \%$ and $76.2 \%$ (Fig. 5). The high MC of the dumped weathered ash (cores S1, S2 and S3) resulted from the wet disposal method used at the petrochemical power utility station which involved mixing the FA with brine and transporting it to the dump in slurry form. This observed high MC could be attributed to seepage of rain water and ash transport water through the dump by natural hydraulic transport. Every time a new layer of ash slurry is placed on top of the dam, more ash transport water must percolate through the dam. The fluctuating trend in the MC in the drilled cores at different depths could be due to different dumping conditions i.e. dumping being done on sunny or rainy days or varying ash layer thickness arising from inconsistent ash placement conditions. The high water content in the ash dam may exacerbate the leaching of soluble species in the FA and increase the risk of the ash dump slumping with time, much like the Kingston fossil plant coal fly ash slurry spill in Tennessee in 2008, due to the high moisture content of the ash layers packed on top of each other during wet dumping.

\subsection{Morphological analysis}

The surface morphologies of the fresh FA sample and the weathered FA samples taken from cores S1, S2 and S3 are shown in the SEM micrographs (Fig. 6). The changes in surface morphology between the fresh FA and the weathered FA are evident from the SEM micrographs. The fresh FA mainly consisted of spherical particles with smooth outer surfaces (Fig. 6A) while the weathered FA from the drilled cores S1, S2 and S3 (Fig. 6BeD respectively) appeared to be encrusted, etched and corroded. Fig. 6D shows a fractured sphere of the weathered FA showing the vesicular interior. The spherical shape of the fresh FA is an indication that the particles were formed under un-crowded free fall conditions and a relatively sudden cooling, which helped to maintain the spherical shape; while the agglomerated nature of some particles is an indication that the particles were produced due to high temperature sintering reactions (Saikia et al., 2006). According to Seames (2003), the smooth outer surfaces of the fresh FA particles are assumed to be mainly aluminosilicate structures. The changes in morphology (encrustations, etchings and corrosion) observed on the surface of the weathered FA samples taken from the drilled cores $\mathrm{S}_{1}, \mathrm{~S}_{2}$ and $\mathrm{S}_{3}$ is as a result of leaching (Praharaj et al., 2002), or the presence of secondary mineral phases such as calcite formed via carbonation process involving the reaction of carbon dioxide with the alkaline materials present in the FA (Yeheyis et al., 2009).

\section{http://repository.uwc.ac.za}




\subsection{Bulk chemical analysis}

Table 1 presents the bulk chemical composition based on XRF analysis of the fresh FA sample and the weathered FA samples taken from cores $\mathrm{S}_{1}, \mathrm{~S}_{2}$ and $\mathrm{S}_{3}$. The composition of the major elements is reported as weight percentage (wt. \%) while the trace elements are reported in parts per million $(\mathrm{mg} / \mathrm{kg})$. The concentrations of the major and trace elements in the fresh FA sample were compared to the mean concentrations of the major and trace elements in the samples of the weathered ash taken from drilled cores S1, S2 and S3.The fresh FA sample generally contained the same major and trace elements as the samples from the weathered drilled cores S1, S2 and S3 (Table 1).

Table 1

Chemical composition of the fresh FA sample and the weathered drilled cores S1, S2 and S3 [number of determinations for fresh ash, S1, S2 and S3 are 3, 45, 105 and 44 respectively].

\begin{tabular}{|c|c|c|c|c|}
\hline Major elements & $\begin{array}{l}\text { Fresh ash } \\
\text { (wt \%) }\end{array}$ & $\begin{array}{l}\text { S1 (mean) } \\
\text { (wt \%) }\end{array}$ & $\begin{array}{l}\text { S2 (mean) } \\
\text { (wt \%) }\end{array}$ & $\begin{array}{l}\text { S3 (mean) } \\
\text { (wt \%) }\end{array}$ \\
\hline $\mathrm{SiO}_{2}$ & 50.86 & 43.46 & 46.24 & 46.61 \\
\hline $\mathrm{Al}_{2} \mathrm{O}_{3}$ & 25.52 & 23.05 & 24.87 & 22.43 \\
\hline $\mathrm{CaO}$ & 8.95 & 8.01 & 8.51 & 8.94 \\
\hline $\mathrm{Fe}_{2} \mathrm{O}_{3}$ & 2.26 & 3.67 & 3.39 & 3.90 \\
\hline $\mathrm{Na}_{2} \mathrm{O}$ & 2.20 & 2.47 & 2.49 & 2.76 \\
\hline $\mathrm{MgO}$ & 1.87 & 2.44 & 2.65 & 2.83 \\
\hline $\mathrm{TiO}_{2}$ & 1.78 & 1.70 & 1.75 & 1.90 \\
\hline $\mathrm{K}_{2} \mathrm{O}$ & 0.95 & 0.97 & 1.04 & 1.29 \\
\hline $\mathrm{P}_{2} \mathrm{O}_{5}$ & 0.71 & 0.67 & 0.73 & 0.77 \\
\hline $\mathrm{MnO}$ & 0.05 & 0.07 & 0.07 & 0.08 \\
\hline $\mathrm{SO}_{3}$ & 0.03 & 0.11 & 0.09 & 0.09 \\
\hline LOI & 4.78 & 13.45 & 8.16 & 8.32 \\
\hline Sum & 99.96 & 100.07 & 99.98 & 99.93 \\
\hline $\mathrm{SiO}_{2} / \mathrm{Al}_{2} \mathrm{O}_{3}$ & 1.99 & 1.89 & 1.86 & 2.08 \\
\hline Trace elements & $\begin{array}{l}\text { Fresh ash } \\
(\mathrm{mg} / \mathrm{kg})\end{array}$ & $\begin{array}{l}\text { S1 (mean) } \\
(\mathrm{mg} / \mathrm{kg})\end{array}$ & $\begin{array}{l}\text { S2 (mean) } \\
(\mathrm{mg} / \mathrm{kg})\end{array}$ & $\begin{array}{l}\text { S3 (mean) } \\
(\mathrm{mg} / \mathrm{kg})\end{array}$ \\
\hline $\mathrm{Sr}$ & 4160 & 4456 & 4490 & 4864 \\
\hline $\mathrm{Ba}$ & 2749 & 2682 & 2804 & 3014 \\
\hline Th & 1922 & 2075 & 2096 & 2283 \\
\hline $\mathrm{Zr}$ & 664 & 667 & 676 & 720 \\
\hline $\mathrm{Ce}$ & 177 & 184 & 173 & 202 \\
\hline Y & 156 & 166 & 164 & 171 \\
\hline $\mathrm{Nb}$ & 109 & 126 & 123 & 141 \\
\hline As & 61 & 91 & 61 & 89 \\
\hline Co & 32 & 33 & 33 & 34 \\
\hline $\mathrm{Pb}$ & 28 & 37 & 37 & 34 \\
\hline $\mathrm{Ni}$ & 23 & 29 & 29 & 32 \\
\hline $\mathrm{Rb}$ & 16 & 16 & 21 & 25 \\
\hline V & 15 & 77 & 70 & 71 \\
\hline
\end{tabular}

nd $=$ not detected. 


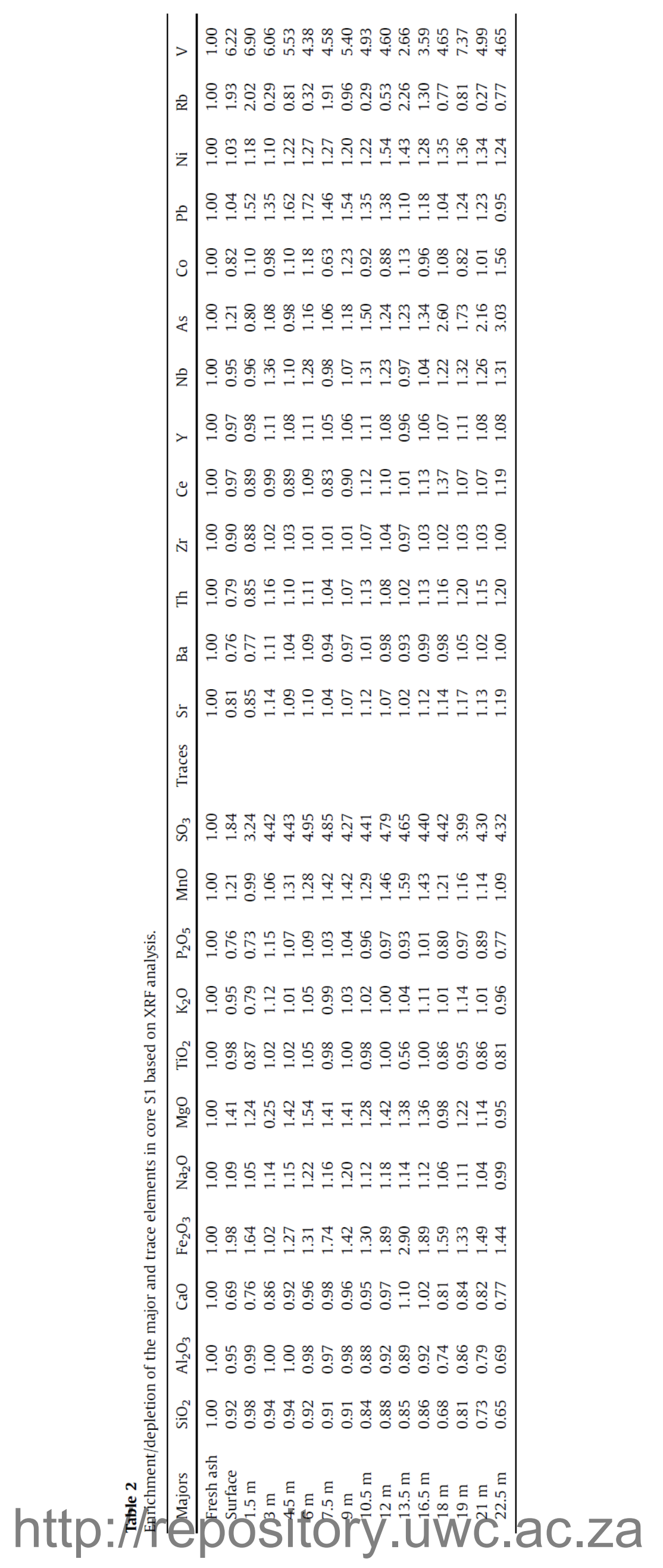


The concentrations of $\mathrm{Si}$ and $\mathrm{Al}$ in the fresh FA were observed to be higher than those of samples taken from the drilled cores $\mathrm{S}_{1}, \mathrm{~S}_{2}$ and $\mathrm{S}_{3}$ (Table 1). The decrease in the concentration (calculated difference in concentrations of the elements in fresh FA samples and samples from the weathered drilled cores) of $\mathrm{SiO}_{2}$ (7.45\%, 4.62\% and 4.30\% in core $\mathrm{S} 1, \mathrm{~S} 2$ and $\mathrm{S}_{3}$ respectively) and $\mathrm{Al}_{2} \mathrm{O}_{3}$ (2.47\%, $0.65 \%$ and $3.09 \%$ in core $\mathrm{S} 1, \mathrm{~S} 2$ and $\mathrm{S} 3$ respectively) compared to the fresh FA sample could be attributed to the weathering process which may have led to the dissolution of the ash matrix and the release of these major elements from the core samples over time. According to Zevenbergen et al. (1999), the leaching of $\mathrm{Si}$ and $\mathrm{Al}$ increases with weathering. The case was different for elements such as $\mathrm{Mn}, \mathrm{Fe}, \mathrm{Na}, \mathrm{Mg}$ and $\mathrm{S}$ where the concentrations of these elements in the core samples were slightly higher than those observed in the fresh FA (Table 1). The slight overall increase in the concentrations of $\mathrm{Na}$ a difference of (0.26\% in core $\mathrm{S} 1,0.29 \%$ in core $\mathrm{S} 2$ and $0.55 \%$ in core $\left.\mathrm{S}_{3}\right)$; $\mathrm{Mg}$ (0.37\% in core $\mathrm{S} 1,0.78 \%$ in core $\mathrm{S} 2$ and $0.96 \%$ in core $\mathrm{S}_{3}$ ) and $\mathrm{S}(0.08 \%$ in core $\mathrm{S} 1$, $0.06 \%$ in core $\mathrm{S}_{2}$ and $0.06 \%$ in core $\mathrm{S}_{3}$ ) in the drilled core samples compared to the fresh FA could be as a result of co-disposal with brine, while the increase in the concentration of $\mathrm{Fe}\left(1.40 \%\right.$ in core $\mathrm{S} 1,1.13 \%$ in core $\mathrm{S}_{2}$ and $1.63 \%$ in core $\left.\mathrm{S}_{3}\right)$ compared to the fresh FA could be attributed to the disposal of spent Fecatalysts on the ash dump where the drilled core samples were collected. According to Nyamhingura (2009), brine from Sasol Secunda power station contains elements such as $\mathrm{Na}, \mathrm{Cl}, \mathrm{Ca}, \mathrm{K}$ and $\mathrm{Mg}$ in high concentrations. Therefore, the slight overall increase in the concentrations of these species in the drilled core samples could be attributed to the FA and brine interaction at the dump. However, considering the high volumes of brine ( 5 times more than the ash) disposed over 20 years of operation of the ash disposal site one would have expected much higher salt content than what was found, had the dump actually captured the salts.

The loss on ignition (LOI) which is an indication of unburnt carbon or organic content was $4.78 \%$ for the fresh FA and $13.45 \%, 8.16 \%$ and $8.32 \%$ for the taken from drilled cores $\mathrm{S} 1, \mathrm{~S} 2$ and $\mathrm{S} 3$ respectively. The LOI of the samples obtained from the three drilled cores S1, S2 and S3 was observed to be enriched in the weathered FA when compared to that of the fresh FA. The higher LOI observed for the drilled cores compared to the fresh FA could indicate high hydrocarbon content in the ash dump because of the co-disposal practice at the power station where hydrocarbon waste is included in the brine stream for disposal on the ash which is the most probable explanation given the water quality. The enrichment in LOI could otherwise be due to changes in burner conditions over time resulting in more or less carbon in the disposed ash, or due to the structural incorporation of $\mathrm{H}_{2} \mathrm{O}$ into secondary mineral phases formed in the disposal of the FA (Yeheyis et al., 2009).

\section{http://repository.uwc.ac.za}




\subsubsection{Classification of the FA}

According to the American Society for Testing and Materials (ASTM C 61892a), FA can be classified as class $\mathrm{F}$ or $\mathrm{C}$ based on the sum of the oxides of aluminium, silicon and iron in the FA. Class F FA is characterised by (i) the sum of $\mathrm{SiO}_{2}, \mathrm{Al}_{2} \mathrm{O}_{3}, \mathrm{Fe}_{2} \mathrm{O}_{3}>70 \%$, (ii) $\mathrm{SO}_{3}<5 \%$, (iii) moisture content $<3 \%$, (iv) loss on ignition (LOI) $<6 \%$ and $(\mathrm{v}) \mathrm{CaO}<20 \%$. The fresh FA and the weathered FA obtained from sampling the three drilled cores $\mathrm{S}_{1}, \mathrm{~S}_{2}$ and $\mathrm{S}_{3}$ was classified as Class $\mathrm{F}$. The sum of the mean concentrations of $\mathrm{SiO}_{2}, \mathrm{Al}_{2} \mathrm{O}_{3}$ and $\mathrm{Fe}_{2} \mathrm{O}_{3}$ was $78.67 \%, 70.19 \%, 74.50 \%$ and $72.94 \%$ for the fresh FA, core S1, core S2 and core S3 respectively (Table 1). The fresh FA contained $8.95 \% \mathrm{CaO}$ while the average percentages contained in samples from cores $\mathrm{S} 1, \mathrm{~S} 2$ and $\mathrm{S} 3$ were $8.01 \%, 8.51 \%$ and 8.95\% $\mathrm{CaO}$ respectively (Table 1 ). The $\mathrm{CaO}$ concentration for the different FA samples was in the mid-range among Class F FA that usually has low calcium content (Vassilev and Vassileva, 2007). The average concentrations of trace elements such as $\mathrm{As}, \mathrm{Ce}, \mathrm{Co}, \mathrm{Cu}, \mathrm{Nb}, \mathrm{Ni}, \mathrm{Pb}, \mathrm{Rb}, \mathrm{V}$ and $\mathrm{Y}$ were observed to be slightly higher in the drilled core samples than in the fresh FA sample (Table 1). This observation could be attributed to the contact of the FA with brine since these trace elements are present in the brine being used for ash transport at the power station as reported by Nyamhingura (2009). XRF technique was used in the analysis of the trace elements instead of ICP-MS technique due to cost constraints.

\subsubsection{Enrichment and depletion of major and trace elements}

The enrichment/depletion factors of major and trace elements in the samples taken from cores S1, S2 and S3were determined in order to understand the changes in the chemical compositions of the drilled core samples as a function of depth at the dump. To calculate the enrichment/depletion factors, the XRF data of the drilled cores $\mathrm{S} 1, \mathrm{~S} 2$ and $\mathrm{S}_{3}$ were normalized with that of the fresh FA, based on a modified formula used by Ogugbuaja and James (1995). The enrichment/depletion factors were calculated as shown in Eq. (4):

The results showing the enrichment/depletion factors of the major and trace elements in the fresh FA and the drilled core $\mathrm{S}_{1}, \mathrm{~S}_{2}$ and $\mathrm{S}_{3}$ samples are presented in Tables 2e4. The values below 1.0 represent relative depletion in relation to the fresh ash while values above 1.0 represent relative enrichment in relation to the fresh ash. The enrichment/depletion factors showed the mobility patterns of the species as a result of the dissolution of the ash matrix and soluble salts contained in the ash. The concentrations of $\mathrm{Si}$ and $\mathrm{Al}$ were depleted in the ash samples from the drilled cores $\mathrm{S}_{1}, \mathrm{~S} 2$ and $\mathrm{S}_{3}$ relative to the fresh FA. The enrichment/depletion trends of Si and Al were somewhat similar in the three drilled cores. Si was consistently depleted down the three drilled cores relative to the fresh FA, except for slight accumulation observed at the bottom of core $\mathrm{S}_{3}$. Al was generally depleted down the three

\section{http://repository.uwc.ac.za}


drilled cores relative to the fresh FA, although the concentration of $\mathrm{Al}$ remained unchanged at $3 \mathrm{~m}, 4.5 \mathrm{~m}$ in core $\mathrm{S}_{1} ; 1.5 \mathrm{~m}, 4.5 \mathrm{~m}, 25.5 \mathrm{~m}$ in core $\mathrm{S}_{3}$; $18 \mathrm{~m}, 21 \mathrm{~m}, 24 \mathrm{~m}, 25.5 \mathrm{~m}, 51 \mathrm{~m}$ in core S2, with slight accumulation at $3 \mathrm{~m}, 36$ $\mathrm{m}, 42 \mathrm{~m}$ and $43.5 \mathrm{~m}$ in core S2. The depletion of Si and Al indicates that these species were continuously leached from the ash as a result of weathering and it is noteworthy as earlier mentioned that the leaching of $\mathrm{Si}$ and $\mathrm{Al}$ from FA increases with weathering. Since Si and $\mathrm{Al}$ form the major matrix of the ash, the progressive leaching of these major elements will lead to the release of other components locked in the ash matrix and indicates the long term instability of the fly ash matrix.

The concentration of $\mathrm{Fe}, \mathrm{Mn}, \mathrm{Na}, \mathrm{K}, \mathrm{Mg}$ and $\mathrm{S}$ were observed to be somewhat enriched consistently in the drilled cores S1, S2 and S3. The slight enrichment in the concentration of $\mathrm{S}$ and $\mathrm{Na}$ maybe as a result of the FA interactions with the co-disposed brine that has a substantial concentration of these species (Mooketsi et al., 2007)

Enrichment/Depletion $=\frac{\text { wt. \% of element in drilled core samples at specific depth }}{\mathrm{wt} \% \text { of the element in fresh fly ash sample }}$

\begin{tabular}{|c|c|c|c|c|c|c|c|c|c|c|c|c|c|c|c|c|c|c|c|c|c|c|c|c|c|}
\hline Majors & $\mathrm{SiO}_{2}$ & $\mathrm{Al}_{2} \mathrm{O}_{3}$ & $\mathrm{CaO}$ & $\mathrm{Fe}_{2} \mathrm{O}_{3}$ & $\mathrm{Na}_{2} \mathrm{O}$ & MgO & $\mathrm{TiO}_{2}$ & $\mathrm{~K}_{2} \mathrm{O}$ & $\mathrm{P}_{2} \mathrm{O}_{5}$ & MnO & $\mathrm{SO}_{3}$ & Traces & $\mathrm{Sr}$ & $\mathrm{Ba}$ & Th & $\mathrm{Zr}$ & $\mathrm{Ce}$ & $\mathrm{Y}$ & $\mathrm{Nb}$ & As & Co & $\mathrm{Pb}$ & $\mathrm{Ni}$ & $\mathrm{Rb}$ & $\mathrm{v}$ \\
\hline Fresh ash & 1.00 & 1.00 & 1.00 & 1.00 & 1.00 & 1.00 & 1.00 & 1.00 & 1.00 & 1.00 & 1.00 & & 1.00 & 1.00 & 1.00 & 1.00 & 1.00 & 1.00 & 1.00 & 1.00 & 1.00 & 1.00 & 1.00 & 1.00 & 1.00 \\
\hline Surface & 0.96 & 0.96 & 0.84 & 1.90 & 1.04 & 1.37 & 0.95 & 0.79 & 0.75 & 1.24 & 2.28 & & 0.82 & 0.70 & 0.81 & 0.91 & 0.61 & 0.90 & 0.96 & 0.78 & 1.05 & 1.48 & 1.05 & 2.15 & 5.73 \\
\hline $1.5 \mathrm{~m}$ & 0.92 & 0.92 & 1.06 & 2.71 & 1.11 & 1.27 & 0.98 & 0.81 & 0.80 & 1.40 & 3.33 & & 0.85 & 0.71 & 0.84 & 0.97 & 0.99 & 0.95 & 0.90 & 1.17 & 1.19 & 1.20 & 1.62 & 2.01 & 5.48 \\
\hline $3 \mathrm{~m}$ & 0.96 & 1.01 & 0.89 & 1.22 & 1.10 & 1.37 & 1.00 & 0.92 & 0.96 & 1.09 & 2.87 & & 0.97 & 0.88 & 0.97 & 0.94 & 0.92 & 1.02 & 1.14 & 0.86 & 0.76 & 1.41 & 1.18 & nd & 6.04 \\
\hline $4.5 \mathrm{~m}$ & 0.86 & 0.91 & 1.11 & 1.78 & 1.17 & 1.35 & 1.02 & 1.05 & 0.96 & 1.40 & 4.09 & & 1.06 & 1.00 & 1.07 & 1.00 & 0.98 & 1.01 & 1.04 & 1.31 & 0.58 & 1.39 & 1.33 & 1.70 & 1.91 \\
\hline $6 \mathrm{~m}$ & 0.90 & 0.94 & 1.09 & 1.99 & 1.12 & 1.49 & 0.97 & 0.99 & 0.95 & 1.59 & 2.94 & & 1.05 & 0.95 & 1.06 & 1.03 & 1.10 & 1.03 & 1.02 & 0.84 & 1.44 & 1.02 & 1.21 & 1.75 & 4.14 \\
\hline $7.5 \mathrm{~m}$ & 0.91 & 0.99 & 0.99 & 1.27 & 1.24 & 1.59 & 0.99 & 0.98 & 1.02 & 1.52 & 2.96 & & 1.07 & 0.92 & 1.08 & 1.04 & 1.03 & 1.11 & 1.15 & 1.07 & 1.08 & 1.96 & 1.34 & 0.93 & 7.44 \\
\hline $9 \mathrm{~m}$ & 0.88 & 0.94 & 1.03 & 1.64 & 1.14 & 1.52 & 0.96 & 0.96 & 0.98 & 1.46 & 3.40 & & 1.04 & 0.96 & 1.05 & 1.04 & 0.92 & 1.07 & 1.00 & 1.05 & 1.29 & 1.42 & 1.39 & 1.08 & 3.83 \\
\hline $10.5 \mathrm{~m}$ & 0.85 & 0.91 & 1.01 & 1.84 & 1.19 & 1.46 & 0.96 & 1.04 & 0.96 & 1.59 & 3.55 & & 1.03 & 0.88 & 1.04 & 1.00 & 1.01 & 1.04 & 0.95 & 1.33 & 0.95 & 1.71 & 1.31 & 2.56 & 4.46 \\
\hline $12 \mathrm{~m}$ & 0.90 & 0.97 & 0.97 & 2.09 & 1.15 & 1.49 & 0.98 & 1.16 & 1.02 & 1.50 & 2.67 & & 1.08 & 0.98 & 1.10 & 1.01 & 0.98 & 0.95 & 1.04 & 0.95 & 0.76 & 1.42 & 1.26 & 2.44 & 3.63 \\
\hline $13.5 \mathrm{~m}$ & 0.92 & 0.97 & 0.96 & 1.42 & 1.16 & 1.45 & 1.03 & 1.19 & 1.07 & 1.29 & 3.52 & & 1.08 & 0.98 & 1.09 & 1.00 & 0.99 & 1.08 & 1.18 & 1.10 & 0.87 & 1.55 & 1.21 & 0.93 & 5.08 \\
\hline $15 \mathrm{~m}$ & 0.92 & 0.99 & 0.93 & 1.39 & 1.15 & 1.43 & 0.99 & 1.18 & 1.02 & 1.26 & 3.21 & & 1.08 & 1.00 & 1.09 & 1.02 & 0.92 & 1.07 & 1.20 & 0.98 & 0.79 & 1.44 & 1.26 & 0.57 & 4.88 \\
\hline $16.5 \mathrm{~m}$ & 0.90 & 0.98 & 1.05 & 1.52 & 1.19 & 1.41 & 1.04 & 1.18 & 1.11 & 1.38 & 4.25 & & 1.13 & 1.02 & 1.15 & 1.03 & 0.96 & 1.06 & 1.12 & 1.02 & 1.19 & 1.52 & 1.25 & 2.11 & 5.47 \\
\hline $18 \mathrm{~m}$ & 0.92 & 1.00 & 0.90 & 1.41 & 1.13 & 1.41 & 1.01 & 1.14 & 1.06 & 1.32 & 3.48 & & 1.10 & 1.05 & 1.12 & 1.01 & 1.01 & 1.08 & 1.10 & 0.99 & 1.14 & 1.51 & 1.19 & 1.03 & 3.49 \\
\hline $19.5 \mathrm{~m}$ & 0.89 & 0.99 & 0.91 & 1.70 & 1.14 & 1.40 & 0.99 & 1.16 & 1.11 & 1.35 & 3.35 & & 1.14 & 1.06 & 1.15 & 1.01 & 1.22 & 1.10 & 1.12 & 1.17 & 0.91 & 1.15 & 1.23 & 0.44 & 4.20 \\
\hline $21 \mathrm{~m}$ & 0.90 & 1.00 & 0.91 & 1.45 & 1.16 & 1.38 & 0.99 & 1.20 & 1.08 & 1.22 & 3.33 & & 1.09 & 1.06 & 1.11 & 1.00 & 0.93 & 1.07 & 1.10 & 0.99 & 0.62 & 1.33 & 1.35 & 1.01 & 5.74 \\
\hline $22.5 \mathrm{~m}$ & 0.90 & 0.98 & 0.93 & 1.49 & 1.14 & 1.39 & 1.02 & 1.11 & 1.06 & 1.28 & 3.47 & & 1.11 & 1.02 & 1.13 & 1.04 & 1.09 & 1.09 & 1.23 & 1.16 & 1.08 & 1.32 & 1.30 & 0.73 & 5.15 \\
\hline $24 \mathrm{~m}$ & 0.90 & 1.00 & 0.90 & 1.45 & 1.14 & 1.34 & 1.00 & 1.19 & 1.13 & 1.26 & 3.09 & & 1.16 & 1.21 & 1.18 & 1.03 & 0.90 & 1.11 & 1.32 & 1.13 & 1.32 & 1.30 & 1.37 & 0.65 & 2.88 \\
\hline $25.5 \mathrm{~m}$ & 0.93 & 1.00 & 0.86 & 1.26 & 1.13 & 1.33 & 0.99 & 1.23 & 1.03 & 1.18 & 3.28 & & 1.13 & 1.02 & 1.15 & 0.98 & 0.84 & 1.07 & 1.30 & 0.88 & 0.70 & 1.16 & 1.21 & 0.43 & 4.38 \\
\hline $27 \mathrm{~m}$ & 0.93 & 0.97 & 0.90 & 1.50 & 1.11 & 1.40 & 0.97 & 1.24 & 1.02 & 1.23 & 3.12 & & 1.04 & 1.02 & 1.05 & 0.98 & 0.92 & 1.01 & 1.12 & 0.92 & 1.02 & 1.44 & 1.24 & 1.43 & 5.52 \\
\hline $28.5 \mathrm{~m}$ & 0.90 & 0.96 & 0.93 & 2.09 & 1.12 & 1.37 & 0.96 & 1.18 & 1.05 & 1.39 & 3.10 & & 1.04 & 1.06 & 1.05 & 0.98 & 0.81 & 0.97 & 1.01 & 1.01 & 1.12 & 1.31 & 1.43 & 2.34 & 4.87 \\
\hline $30 \mathrm{~m}$ & 0.92 & 0.98 & 0.88 & 1.35 & 1.10 & 1.37 & 0.98 & 1.21 & 1.10 & 1.24 & 2.92 & & 1.07 & 1.10 & 1.08 & 1.01 & 1.13 & 1.05 & 1.29 & 1.01 & 1.23 & 1.28 & 1.34 & 0.05 & 4.77 \\
\hline $31.5 \mathrm{~m}$ & 0.91 & 0.97 & 0.92 & 1.63 & 1.14 & 1.37 & 0.98 & 1.20 & 0.99 & 1.31 & 3.08 & & 1.08 & 1.04 & 1.09 & 1.01 & 0.87 & 1.04 & 1.02 & 1.10 & 1.38 & 1.53 & 1.40 & 2.21 & 3.78 \\
\hline $33 \mathrm{~m}$ & 0.90 & 0.97 & 0.95 & 1.62 & 1.13 & 1.37 & 1.00 & 1.16 & 1.04 & 1.37 & 2.98 & & 1.06 & 1.03 & 1.06 & 1.04 & 0.97 & 1.04 & 1.05 & 1.11 & 1.18 & 1.49 & 1.54 & 1.16 & 5.26 \\
\hline $34.5 \mathrm{~m}$ & 0.92 & 0.96 & 0.91 & 1.63 & 1.10 & 1.43 & 0.99 & 1.23 & 0.99 & 1.27 & 2.92 & & 1.12 & 1.01 & 1.14 & 1.04 & 1.04 & 1.04 & 1.18 & 1.01 & 1.08 & 1.16 & 1.34 & 1.51 & 2.18 \\
\hline $36 \mathrm{~m}$ & 0.94 & 1.01 & 0.88 & 1.32 & 1.06 & 1.35 & 1.01 & 1.17 & 1.09 & 1.29 & 2.70 & & 1.09 & 1.04 & 1.10 & 1.06 & 0.96 & 1.07 & 1.25 & 1.03 & 1.35 & 1.38 & 1.24 & nd & 4.06 \\
\hline $37.5 \mathrm{~m}$ & 0.90 & 0.95 & 0.90 & 1.23 & 1.05 & 1.37 & 0.96 & 1.24 & 1.01 & 1.20 & 2.67 & & 1.13 & 1.04 & 1.14 & 1.05 & 1.06 & 1.08 & 1.14 & 1.11 & 0.79 & 1.44 & 1.24 & 0.67 & 5.45 \\
\hline $39 \mathrm{~m}$ & 0.90 & 0.95 & 1.04 & 1.44 & 1.09 & 1.42 & 0.96 & 1.18 & 1.04 & 1.46 & 2.67 & & 1.06 & 1.03 & 1.07 & 1.05 & 1.07 & 1.03 & 0.96 & 1.09 & 0.85 & 1.07 & 1.23 & 2.00 & 2.42 \\
\hline $40.5 \mathrm{~m}$ & 0.93 & 0.98 & 0.92 & 1.17 & 1.11 & 1.46 & 0.98 & 1.21 & 1.04 & 1.25 & 2.76 & & 1.07 & 1.02 & 1.08 & 1.02 & 0.97 & 1.07 & 1.19 & 0.70 & 0.79 & 0.88 & 1.28 & 0.67 & 6.51 \\
\hline $42 \mathrm{~m}$ & 0.96 & 1.01 & 0.82 & 1.09 & 1.08 & 1.49 & 0.90 & 1.13 & 0.96 & 1.25 & 2.24 & & 1.04 & 1.04 & 1.04 & 1.01 & 1.02 & 1.03 & 1.20 & 0.66 & 1.28 & 1.04 & 1.21 & 0.51 & 3.91 \\
\hline $43.5 \mathrm{~m}$ & 0.93 & 1.01 & 0.95 & 0.95 & 1.15 & 1.46 & 1.01 & 1.10 & 1.10 & 1.25 & 2.76 & & 1.23 & 1.16 & 1.26 & 1.04 & 0.91 & 1.12 & 1.19 & 0.79 & 0.60 & 1.07 & 1.30 & 1.09 & 4.14 \\
\hline $45 \mathrm{~m}$ & 0.92 & 0.99 & 0.98 & 1.12 & 1.16 & 1.40 & 1.02 & 1.08 & 1.08 & 1.34 & 2.64 & & 1.13 & 1.10 & 1.15 & 1.05 & 0.92 & 1.04 & 1.18 & 0.97 & 0.78 & 1.37 & 1.35 & 2.77 & 5.52 \\
\hline $46.5 \mathrm{~m}$ & 0.90 & 0.98 & 0.91 & 1.22 & 1.14 & 1.49 & 0.97 & 1.03 & 1.07 & 1.27 & 2.83 & & 1.11 & 1.11 & 1.12 & 1.05 & 1.06 & 1.06 & 1.11 & 0.84 & 0.75 & 1.17 & 1.33 & 1.22 & 4.02 \\
\hline $48 \mathrm{~m}$ & 0.84 & 0.97 & 1.02 & 1.28 & 1.16 & 1.52 & 0.88 & 0.89 & 1.09 & 1.26 & 2.77 & & 1.24 & 1.19 & 1.26 & 1.03 & 1.01 & 1.15 & 1.18 & 0.90 & 1.13 & 1.24 & 1.42 & 0.49 & 3.93 \\
\hline $49.5 \mathrm{~m}$ & 0.90 & 0.99 & 0.97 & 1.15 & 1.13 & 1.48 & 1.00 & 0.84 & 1.15 & 1.37 & 3.02 & & 1.13 & 1.14 & 1.14 & 1.11 & 0.92 & 1.13 & 1.06 & 0.91 & 1.46 & 1.18 & 1.31 & 0.48 & 5.16 \\
\hline $51 \mathrm{~m}$ & 0.87 & 1.00 & 1.03 & 1.15 & 1.15 & 1.46 & 0.99 & 0.85 & 1.32 & 1.27 & 2.87 & & 1.12 & 1.17 & 1.14 & 1.05 & 1.16 & 1.10 & 1.37 & 1.04 & 1.12 & 1.60 & 1.45 & 0.42 & 3.89 \\
\hline
\end{tabular}




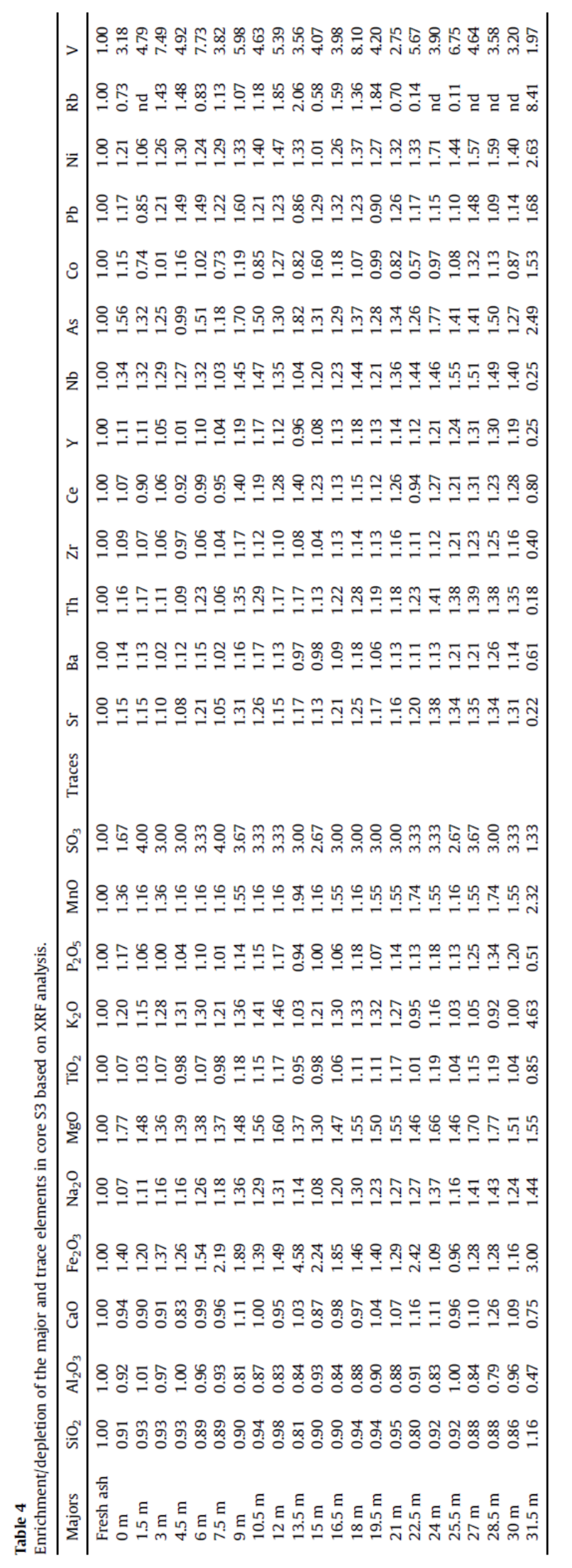

http://repository.uwc.ac.za 
Though high enrichment of $\mathrm{Na}$ in the drilled cores would have been expected due to the large amount of salt laden brine disposed on the dump over 20 years, it is noteworthy that $\mathrm{Na}_{2} \mathrm{O}$ levels remained below 2 weight \% in all samples showing that the dump is not holding or encapsulating $\mathrm{Na}$ to any significant extent. This shows that the salt holding capacity of the ash dump is very low which has a major implication for using it as a salt sink.

According to Lee and Spears (1997), the interaction of dumped FA with infiltrating pore water leads to the depletion of $\mathrm{CaO}$ as a result of leaching and weathering. This explains why Ca was depleted at most of the depths along the drilled cores S1, S2 and S3 compared to the fresh FA. The geophysics electrical resistivity survey profile (Fig. 1) indicated a fault line (crack) in the dump at the position of core $\mathrm{S}_{3}$ which reported the enrichment of Ca. This observed enrichment may have resulted due to the accumulation of brine components in preferential leaching pathways or the formation of some secondary mineral phases in the fault. This observation highlights the inhomogeneity of the ash dump.

The concentrations of trace elements in the samples obtained from the drilled cores $\mathrm{S} 1, \mathrm{~S} 2$ and $\mathrm{S} 3$ were observed to have similar trends. In all the three cores, the concentrations of $\mathrm{Pb}, \mathrm{V}, \mathrm{Zn}, \mathrm{Cr}, \mathrm{Ni}$ and Co were observed to be somewhat enriched along the entire cores. Previous studies have reported the presence of the trace elements in the petrochemical power utility's brine (Mooketsi et al., 2007; Nyamhingura, 2009). Therefore, the slight enrichment of these trace elements in the drilled core samples could be due to the contact of the dumped FA with the co-disposed brine.

The inhomogeneous enrichment and depletion of elements observed along the entire length of the three drilled cores could be explained by the processes occurring in the dam involving the precipitation, dissolution versus flushing of the soluble salts bearing various elements as a result of rain water infiltration and the percolation of brine co-disposed with the FA. From the enrichment and depletion data (Tables 2e4), no significant enrichment or accumulation of any particular element was observed in samples taken from the three drilled cores $\mathrm{S} 1, \mathrm{~S} 2$ and $\mathrm{S} 3$ compared to the fresh FA.

\subsection{Mineralogical analysis}

Fig. 7 shows the XRD patterns of the fresh FA and the drilled cores S1, S2 and S3. XRD was applied in order to identify the mineralogical phases present in the fresh FA and any changes taking place over time in the drilled cores at different depths. The XRD results revealed that the major crystalline mineral phases for the fresh FA samples were quartz $\left(\mathrm{SiO}_{2}\right)$ and mullite $\left(\mathrm{Al}_{6} \mathrm{Si}_{2} \mathrm{O}_{13}\right)$. Lime $(\mathrm{CaO})$ was also identified in the fresh FA but was present in low amounts as can be seen from the relatively minor peaks when compared to those of

\section{http://repository.uwc.ac.za}


quartz and mullite. According to Singh and Kolay (2002), quartz and mullite are the major crystalline constituents of coal FA. Quartz is a hard mineral commonly found as cell and pore infillings in the organic matter of coal and is regarded as a primary mineral. It is basically considered as non-reactive in combustion processes due to its high fusion temperature (Ward, 2002). Mullite is a secondary mineral that is assumed to be formed during the thermal decomposition of kaolinite, an aluminosilicate mineral in the coal (Koukouzas et al., 2009, White and Case, 1990). Lime, which is also a secondary mineral may have resulted from the decomposition of calcite or dolomite, which are the most important and common calcium-bearing minerals in coal.

Core $\mathrm{S} 1$ showed quartz and mullite as the major crystalline mineral phases from the surface down to the depth of $16.5 \mathrm{~m}$ (Fig. 7). Lime and calcite $\left(\mathrm{CaCO}_{3}\right)$ were also identified in core S1 but as minor peaks (Fig. 7). Calcite is a secondary mineral formed by contact of lime $(\mathrm{CaO})$ contained in the FA with ingressed $\mathrm{CO}_{2}$ (Vassilev and Vassileva, 1996). At $22.5 \mathrm{~m}$, apart from quartz and mullite, minor phases of kaolinite $\left(\mathrm{Al}_{2}\left(\mathrm{Si}_{2} \mathrm{O}_{5}\right)(\mathrm{OH})_{4}\right)$ and nitratine $\left(\mathrm{NaNO}_{3}\right)$ were also identified in core S1. Nitratine is a tertiary mineral that may have resulted from the interaction of brine with the FA or may be due to the drying process in the sample prepa- ration prior to analysis. The kaolinite identified at $22.5 \mathrm{~m}$ (bottom of core $\mathrm{S} 1$ ) may have been derived from the erosion of the rock and soil surrounding the ash dump. It could also have resulted from the alteration of the glass phase or weathering of the ash in the dump (Ward et al., 2009). 


\section{Fresh ash and core $\mathrm{S} 1$}

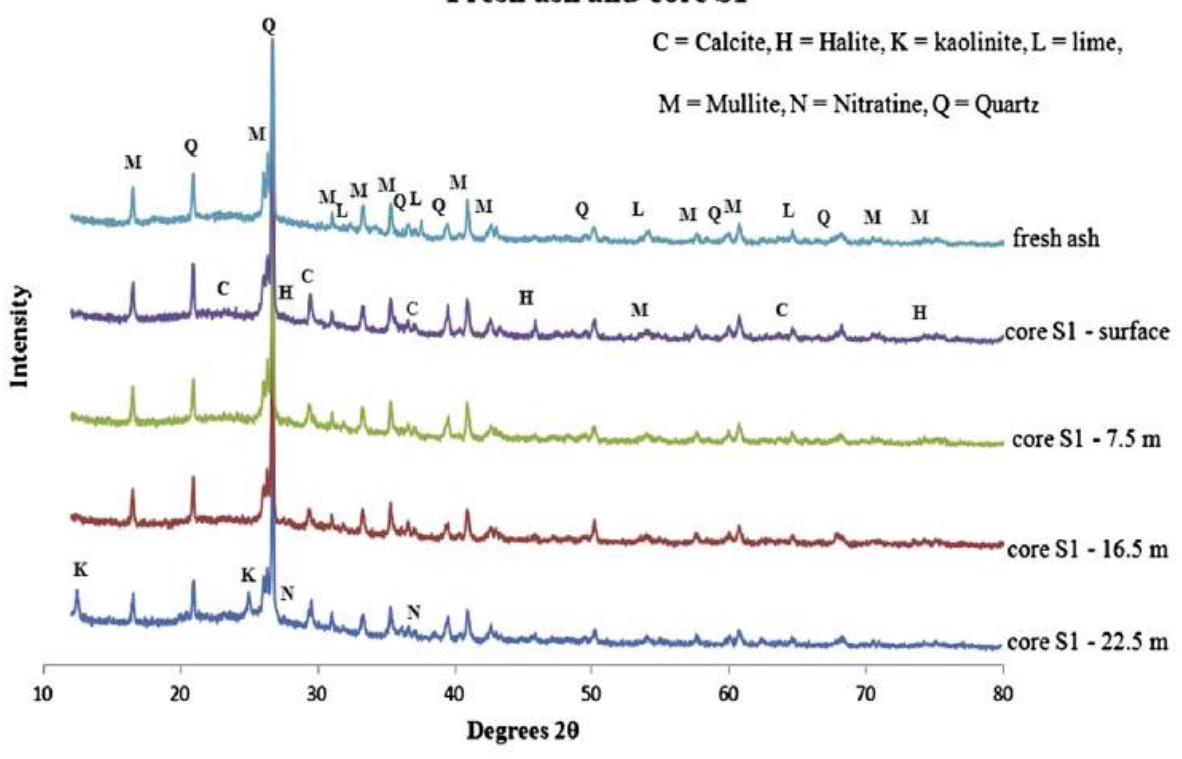

Fresh ash and core S2

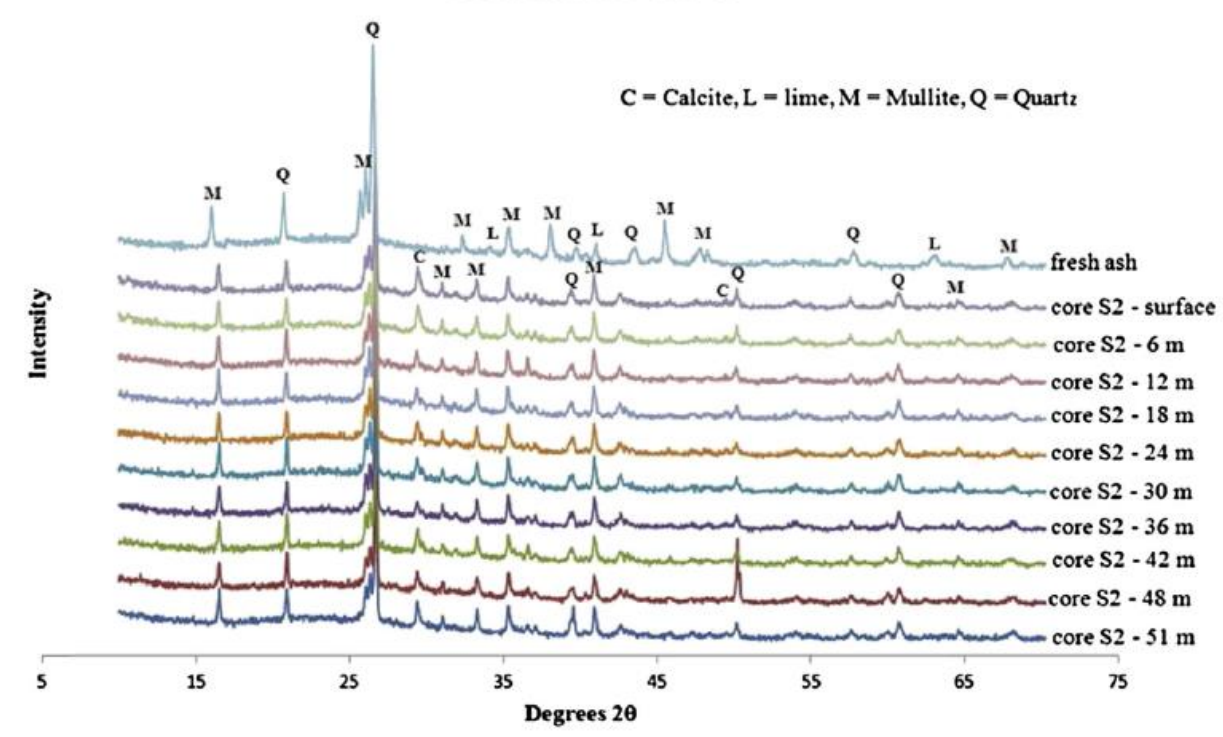

Fresh ash and core $\mathrm{S} 3$

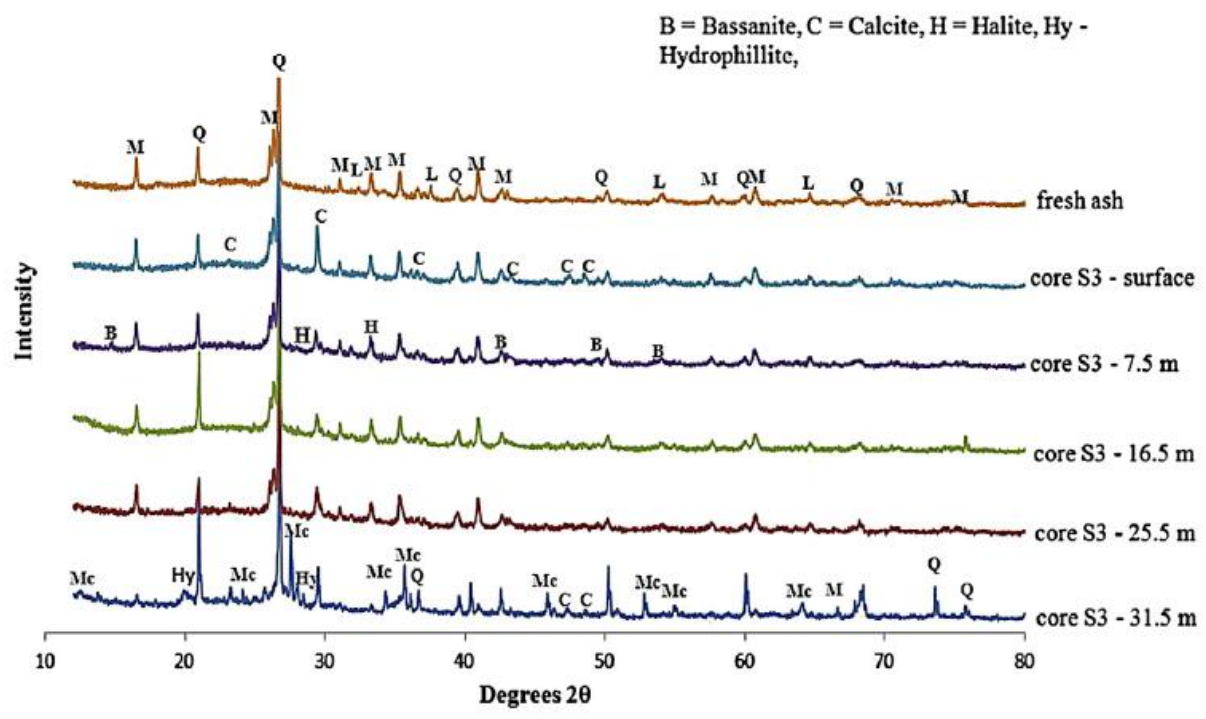

Fig. 7. XRD patterns for the fresh FA sample and the weathered drilled cores S1, S2 and S3 sampled at different depths. 
Core S2 showed three crystalline mineral phases namely quartz, mullite and calcite (Fig. 7) which are common mineral phases found in weathered coal FA (Rao and Gluskoter, 1973). The XRD patterns showed a similar trend for core S2 from the surface sample, along the core down to the bottom of the ash dam. The three crystalline mineral phases identified in core S2 remained consistent at every sampling depth (Fig. 7). All the mineral phases detected by XRD in core $\mathrm{S} 2$ corresponded to the significant levels of $\mathrm{Si}, \mathrm{Al}$ and $\mathrm{Ca}$ contained in the fresh FA and the weathered FA as reported by XRF analysis (Table 1). The lower levels of elements like $\mathrm{Fe}$ and $\mathrm{Mg}$, for example, may have made it difficult to detect any mineral phases associated with them such as hematite $\left(\mathrm{Fe}_{2} \mathrm{O}_{3}\right)$ and enstatite $\left(\mathrm{Mg}_{2} \mathrm{Si}_{2} \mathrm{O} 6\right)$ by the XRD. However, other mineral phases present in core $\mathrm{S} 2$ were not detected by XRD probably because they were in a transition/amorphous state, or present in very low thus undetectable levels. Core S2 did not show mineralogical inhomogeneity but rather gave a consistent trend from the top to the bottom of the core.

Core S3 showed quartz and mullite as the major crystalline mineral phases and calcite as the minor phase at the surface of the ash dump (Fig. 7). Core S3 presented a unique transformation in mineralogy down the depth of the ash dump. At $7.5 \mathrm{~m}, 16.5 \mathrm{~m}$ and $25.5 \mathrm{~m}$, the major crystalline mineral phases were quartz and mullite with calcite, halite $(\mathrm{NaCl})$ and bassanite $\left(\mathrm{CaSO}_{4} \$ 2 \mathrm{H}_{2} \mathrm{O}\right)$ showing up as minor phases (Fig. 7). At $31.5 \mathrm{~m}$ in core $\mathrm{S}_{3}$, quartz was the major phase. Other minerals also tentatively identified at this depth in minor quantities were calcite, microcline $\left(\mathrm{KAlSi}_{3} \mathrm{O} 8\right)$ and hydrophitte $\left(\mathrm{CaCl}_{2}\right)$ (Fig. 7). Halite, bassanite, nitratine, hydrophitte, microcline and albite low are considered as transient minerals that may have formed from the interaction of brine with the FA. According to Alai et al. (2005), halite, bassanite and nitratine may form during brine evolution in complex aqueous systems at elevated temperatures.

The XRD spectra of the FA samples extracted at different depths of cores S1 and S3 were inconsistent in terms of secondary mineral phases although the major mineral components in all cases were quartz, calcite and mullite regardless of the sampling depth. The quartz peaks of the drilled core samples are quite prominent and have a tendency to obscure other less abundant or less crystalline mineral phases. This as well as the fact that samples cannot be analysed in situ without drying is one of the major limitations of XRD analysis. The geophysics electrical resistivity survey profile of the ash dump (Fig. 1) similarly provides clues to explaining the observed mineralogy in cores $\mathrm{S}_{1}$ and $\mathrm{S}_{3}$. Contact with rocks prevented coring to deeper depths in cores $\mathrm{S}_{1}$ and S3. Furthermore, the geophysics of core $\mathrm{S}_{3}$ also showed indication of a fault (crack) at a depth of $16.5 \mathrm{~m}$ which coincided with the point

\section{http://repository.uwc.ac.za}


where the new mineral phases were found. This may indicate a preferred flow pathway for the brine, resulting in a region with saturated conditions promoting the precipitation of various salts in a localized region of the dump.

\section{Conclusion}

The high volumes of brine that pass through the ash dump in the wet ash handling system present a great environmental concern, considering the fact that brine introduces salts and some toxic elements into the FA during codisposal of the two wastes. The high moisture content associated with the wet ash handling system creates an environment that is more conducive to the release of species from the disposed ash. Leaching and weathering process led to the morphological changes observed on the surface of the weathered FA samples. The major mineral phases that were identified in the weathered ash were quartz, mullite and calcite. The transient minerals that were identified in the weathered ash may have been formed from the interaction of brine with the FA, or during sample preparation prior to XRD analysis. The decrease in $\mathrm{pH}$ in the ash dump led to the progressive weathering dissolution of the major aluminosilicate ash matrix which consequently influenced the release of other elements previously locked in the ash matrix. This establishes the role that $\mathrm{pH}$ plays in the mobility patterns of various species in the ash dump. Lower EC observed in the weathered ash compared to the fresh FA indicated a significant loss of ionic species from the dumped weathered ash. TDS followed the same trend as that observed for the EC. Low TDS observed in the weathered ash compared to the fresh FA suggested poor salt sink capacity of the FA dump since the TDS would have been considerably higher in the weathered ash if the FA dump was holding salts.

The slight enrichment of some species e.g. $\mathrm{Mg}, \mathrm{K}, \mathrm{SO}_{4}$ and $\mathrm{Na}$ that was observed in the disposed weathered FA was attributed to the interaction of the fly ash with brine. However, there was no significant accumulation of the various species in the disposed FA despite continuous addition of large volumes of salt laden brine over the 20 year period that the dam existed, which meant that the ash dump did not sustainably accumulate salts but released these elements to the environment.

\section{Acknowledgements}

The authors would like to acknowledge the support of the University of the Western Cape, Environmental and Nano Sciences Research Group, the South African National Research Foundation (NRF), Eskom and Sasol.

\section{http://repository.uwc.ac.za}




\section{References}

Akinyemi, S.A., 2011. Geochemical and Mineralogical Evaluation of Toxic Contaminants Mobility in Weathered Coal Fly Ash: As a Case Study, Tutuka Dump Site, South Africa. Ph.D. thesis. Department of Geology, University of the Western Cape.

Alai, M., Sutton, M., Carroll, S., 2005. Evaporative evolution of a NaeCleNO3eKe CaeSO4eMgeSi brine at 95(degree)C: experiments and modeling relevant to Yucca Mountain, Nevada, USA. Geochemical Transactions 6 (2).

America Society for Testing and Material, 1993. ASTM C 618: Standard speciation for fly ash and raw or calcined natural pozzolan for use as amineral admixture in Portland cement concrete. In: Annual Book of ASTM Standards. ASTM, Philadelphia, PA.

Baba, A., Gurdal, G., Sengunalp, F., Ozay, O., 2008. Effects of leachant temperature and $\mathrm{pH}$ on leachability of metals from fly ash. A case study: can thermal power plant, province of Canakkale, Turkey. Environmental Monitoring Assessment 139, 287-298. http://dx.doi.org/10.1007/s10661-007-9834-8.

Bhattacharyya, S., Donahoe, R.J., Patel, D., 2009. Experimental study of chemical treatment of coal fly ash to reduce the mobility of priority trace elements. Fuel 88, 1173-1184.

Brower, G.R., 1985. Solid wastes and water quality. Journal of Water Pollution Control Federation 57 (6), 625-629.

Dutta, B.K., Khanra, S., Mallick, D., 2009. Leaching of elements from coal fly ash: assessment of its potential for use in filling abandoned coal mines. Fuel 88, 1314-1323.

Gitari, W., Fatoba, O., Petrik, L., Vadapalli, V., 2009. Leaching characteristics of selected South African fly ashes: effect of $\mathrm{pH}$ on the release of major and trace species. Journal of Environmental Science and Health, Part A: Toxic/Hazardous Substances and Environmental Engineering 44 (2), 206-220, 1532-4117.

Hlatshwayo, B., Matjie, H., Li, Z., Ward, R., 2009. Mineralogical characterization of sasol feed coals and corresponding gasification ash constituents. Energy \& Fuels 23, 2867-2873.

Koukouzas, N., Ward, C., Papanikolaou, D., Li, Z., Ketikidis, C., 2009. Quantitative evaluation of minerals in fly ashes of biomass, coal and biomass-coal mixture derived from circulating fluidised bed combustion technology. Journal of Hazardous Materials 169, 100107.

Lee, S., Spears, D., 1997. Natural weathering of pulverized fuel ash and porewater evolution. Applied Geochemistry 12, 367-376,.

Liu, G., Vassilev, S.V., Gao, L., Zheng, L., Peng, Z., 2005. Mineral and chemical composition and some trace element contents in coals and coal ashes from Huaibei coal field, China. Energy Conversion 
and Management 46, 2001e2009. Mangena, S., 2009. Effective utilisation of coal in Sasol e a Sasol FBDB gasification technology perspective. In: SACPS International Conference "Coal Powering the Future" e Secunda, South Africa 2009.

Matjie, H., Ginster, M., Van Alphen, C., Sobiecki, A., 2005. Detailed characterization of Sasol ashes. http://whocares.caer.uky.edu/wasp/AshSymposium/AshLibrary Agenda.asp\#2005.

Mooketsi, I.O., Ginster, M., Matjie, H.R., Riedel, J.K., 2007. Leachate Characteristics of Ash Residues from a Laboratory Scale Brine Encapsulation Simulation Process. World of Coal Ash (WOCA), Kentucky, USA.

Nyamhingura, A., 2009. Characterization and Chemical Speciation Modelling of Saline Effluents at Sasol Synthetic Fuels ComplexSecunda and Tutuka Power Station. M.Sc. thesis. Department of Chemistry, University of the Western Cape.

Ogugbuaja, V., James, W., 1995. INAA multielemental analysis of Nigerian bituminous coal and coal ash. Journal of Radio analytical and Nuclear Chemistry 191, 181-187.

Praharaj, T., Powell, M., Hart, B., Tripathy, S., 2002. Leachability of elements from sub-bituminous coal fly ash from India. Environment International 27, 609e615.

Petrik, L., Akinyeye, R.O., Gitari, W.M., Nel, J., Fatoba, O., Akinyemi, S.A., Eze, P., Nyale, S., 2010. Towards the Development of Sustainable Salt Sinks: Fundamental Studies on the Co-Disposal of Brines within Inland Ash Dams. Sasol/Eskom phase two 6th Quarter interim report.

Potgieter, J.H., 2003. Fly ash research at Technikon Pretoria, South Africa. Energeia 14 (1), 1 e6.

Potgieter-Vermaak, S., Potgieter, J., Kruger, R., Spolink, Z., Van Grieken, R., 2005.

A characterisation of the surface properties of ultra fine fly ash (UFFA) used in the polymer industry. Fuel 84, 2295-2300.

Rao, C.P., Gluskoter, H.J., 1973. Occurrence and distribution of minerals in Illinois coals, Illinois State Geological Survey, Circular 476.

Saikia, N., Kato, S., Kojima, T., 2006. Composition and leaching behaviour of combustion residues. Fuel 85, 264-271.

Seames, W.S., 2003. An initial study of the fine fragmentation fly ash particle mode generated during pulverized coal combustion. Fuel Processing Technology 81, 109-125.

Singh, D.N., Kolay, P.K., 2002. Simulation of ash-water interaction and its influence on ash characteristics. Progress in Energy and Combustion Science 28, 267-299. 
Standards Association of Australia. AS 1289 B1.1e1977: Determination of the Moisture Content of a Soil: Oven Drying Method (standard method).

Ugurlu, A., 2004. Leaching characteristics of fly ash. Environmental Geology 46, 890-895. http://dx.doi.org/10.1007/s00254-004-11006.

Vadapalli, V., Gitari, W., Ellendt, A., Petrik, L., Balfour, G., 2010. Synthesis of zeolite-P from coal fly ash derivative and its utilisation in mine-water remediation. South African Journal of Science 106 (5/6), 7. Art.\#231.

Vassilev, S., Vassileva, C., 1996. Mineralogy of combustion wastes from coal-fired power stations. Fuel Processing Technology 47, 261-280.

Vassilev, S., Vassileva, C., 2005. Methods for characterization of composition of fly ashes from coal-fired power stations: a critical overview. Energy \& Fuels 19, 1084-1098.

Vassilev, S., Vassileva, C., 2007. A new approach for the classification of coal fly ashes based on their origin, composition, properties and behavior. Fuel 86, 1490-1512.

Ward, C.R., 2002. Analysis and significance of mineral matter in coal seams. International Journal of Coal Geology 50, 135-168.

Ward, C., French, D., Jankowski, J., Dubikova, M., Li, Z., Riley, K., 2009. Element mobility from fresh and long-stored acidic fly ashes associated with an Australian power station. International Journal of Coal Geology 80, 224-236.

White, S., Case, E., 1990. Characterization of fly ash from coal-fired power plants.

Journal of Material Science 25, 5215e5219. www.eskom.co.za. www.hannainst.com. www.marscigrp.org/oxtoel.html.

Yeheyis, M., Shang, J., Yanful, E., 2009. Chemical and mineralogical transformations of coal fly ash after landfilling, 2009, World of coal ash (WOCA) conference-May 4e7, Lexington Ky, USA. http://www.flyash.info/.

Zevenbergen, C., Bradley, J., Piet Van Reeuwijk, L., Shyam, A., Hjelmar, O., Comans, R., 1999. Clay formation and metal fixation during weathering of coal fly ash. Environmental Science \& Technology 33, 3405-3409. Applied Energy Research, University of Kentucky, Paper \#1. 